Kader

e-ISSN: 2602-2710

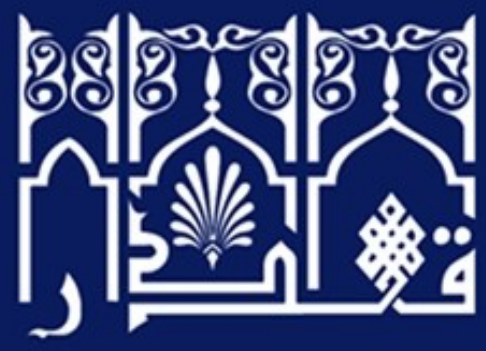

Cilt: 19, Say1: 1, 2021, ss. 146-176 ｜ Volume: 19, Issue: 1, 2021, pp. 146-176

\title{
İslam Düşüncesinde İnsan Fiilleri: Farklı Söylemler Ortak Amaçlar
}

Human Acts in Islamic Thought: Different Discourses Common Purposes

\section{Bilal TAŞKIN}

Dr. Öğr. Üyesi, Çanakkale Onsekiz Mart Üniversitesi, İlahiyat Fakültesi, Çanakkale/Türkiye Assistant Professor, Çanakkale Onsekiz Mart University, Faculty of Theology, Çanakkale/Turkey $\underline{\text { m.taskinbilal@gmail.com | orcid.org/0000-0001-7253-0623 | ror.org/05rsv8p09 }}$

\author{
Makale Bilgisi Article Information \\ Makale Türü Article Type \\ Araştırma Makalesi Research Article \\ Geliş Tarihi Date Recieved \\ 15 Nisan $2021 \quad 15$ April 2021 \\ Kabul Tarihi Date Accepted \\ 22 Haziran $2021 \quad 22$ June 2021 \\ Yayın Tarihi Date Published \\ 30 Haziran 202130 June 2021 \\ Intihal Plagiarism
}

Bu makale, iTenticate yazılımı ile taranmıştır. İntihal This article has been scanned with iTenticate

tespit edilmemiştir. software. No plagiarism detected.

Etik Beyan Ethical Statement

Bu çalışmanın hazırlanma sürecinde bilimsel ve etik

ilkelere uyulduğu ve yararlanılan tüm çalışmaların

It is declared that scientific and ethical principles have been followed while carrying out and writing

kaynakçada belirtildiği beyan olunur (Bilal Taşkın). this study and that all the sources used have been properly cited (Bilal Taşkın).

CC BY-NC-ND 4.0 lisansı ile lisanslanmıştır. Licensed under CC BY-NC-ND 4.0 license.

Atıf | Cite As

c Taşkın, Bilal. "İslam Düşüncesinde İnsan Fiilleri: Farklı Söylemler Ortak Amaçlar”. Kader 19/1 (Haziran 2021), 146-176. https://doi.org/10.18317/kaderdergi.916808 


\section{Öz}

İnsan fiilleri konusu, ilk dönemlerden itibaren kelâm ilminin tartışmalı konuları arasında yer almıştır. İlâhî sıfatlardan kaza ve kadere, hüsün kubuh meselesinden aklın sınırlarına, imkânsız şeylerle sorumluluktan akla dayalı sorumluluğa, cevher araz bahislerinden nedenselliğe, kudret kavramının analizinden ahlâkî davranışların kaynağına kadar birçok mesele ile doğrudan ya da dolaylı olarak irtibatlı olan insan fiilleri konusu etrafında İslam düşünce tarihi içerisinde birçok şey söylenmiş ve yazılmıştır. Bu çalışmada insan fiilleri meselesi, hususen, Allah'ın ilim, irade ve kudreti karşısında insanın fiili üzerindeki etkisi kapsamında ele alınmıştır. Bu meselede Mu'tezile, Allah'ın, kendi iradesi ve hikmeti gereğince, insana verdiği kudret ile onun iyi ve kötü fiillerini yapma ve terk etme konusunda bağımsız olduğunu, insanın yaptığı kötü eylemlerin, herhangi bir şekilde Allah'ın sıfatlarıyla ilişkilendirilemeyeceğini savunur. Sünnî kelâmcılar, insanın eylemlerini, insanda yaratılan hâdis kudret ile Allah'ın var ettiğini, kötü fiillerin ise yaratılma yönüyle Allah'a, yaratılma sebebi olarak insanın kesbine/iradesine nispet edilmesi gerektiğini ileri sürerler. Bununla birlikte sünnî kelâmın temsilcileri Mâtürîdîler ve Eş̧arîler insanın fiili üzerindeki etkinliğini ifade eden kesbin mâhiyetinin ne olduğu hususunda ayrışırlar. Mâtürîdîler kesbin mevcut/somut bir şey olduğunu söylemekten kaçınırken, Eş̧arîlerde kesbin, Allah'in yaratılan bir fiili olduğu kanaati ön plana çıkmaktadır. Kelâmcıların ilâhî sıfatlar ve tabiattaki hareketlerin/fiillerin işleyişi gibi konularda tartışma halinde oldukları Meşşâ̂ felsefeciler ise insan fiillerini İlk ílke'den feyz eden ezelî neden-sonuç zincirinin bir halkası olarak değerlendirirler. Bununla birlikte onlara göre bu zincirin her halkası ilâhî inâyet ile meydana gelmektedir. Onlar ayrıca ahlâken kötü kabul edilen fiilleri, her yönden tam ve hayır olan İlk i̇lke'ye değil, neden-sonuç sürecindeki fâil nedenlere nispet ederler. Özet olarak hem kelâmcılara hem de felsefecilere göre insanın fillerinin nihâ̂̂ kaynağı ilâhî irade ve kudrettir. Ahlâken ya da dinen kötü olan fiiller insanın iradesine bağlı olarak meydana gelirler. İnsan, iradesi ya da kudreti nedeniyle yaptığı eylemlerden sorumludur. Bu hususlarda hemfikir olan felsefeciler ve kelâmcılar bu meseledeki görüşlerini farklı kavram ve ilkeleri merkeze alarak izah etmişler; temelde aynı fikri anlatmak isterken söylem tarzlarında ve tâlî ilkelerde farklı bir tutum sergilemişlerdir. Bu farklılık şu sorular ekseninde kendini göstermiştir: Sorumluluk, fiili var eden güce mi, fiili belirleyen iradeye mi dayanır? İnsanın iradesine bağlı olarak kötü bir fiili yaratması nedeniyle Allah'a kötülük nispet edilir mi? Âlemin, İlk İlke olan Allah'tan, O'nun bilgisi ve zâtı gereği sâdır olması Allah'in iradesiz ve etkisiz bir fâil olmasını ve dolayısıyla insanın, fiilleri üzerinde etkisi olmayan mecbur bir neden/fâil olmasını gerektirir mi? Kelâmcılar ve felsefeciler bu soruların cevapları bağlamında farklı görüşler ortaya koymuş olsalar da onlar yukarıda değindiğimiz hususlarda ittifak etmişlerdir. Bu çalışmada İslam düşünce tarihinde derin ayrışmalara neden bir problemin arka planında ortak bir amacın olduğu fikri ortaya konulmaya çalışılmış ve İslam düşünce tarihinin söylenenler üzerinden değil de söylenmek istenenler üzerinden okunmasının, dışlayıcı olmayan ve sınırları genişleten yeni açılımlar sağlayabileceğine işaret edilmiştir. Çalışmanın başlıca kaynakları adı geçen düşünce ekollerinin temel metinleridir. Çalışmanın inceleme alanı, insanın fiilleri üzerindeki etkisi ile sınırlandırılmıştır. Çalışma ana bölüm ve sonuç bölümü olmak üzere iki kısımdan oluşmaktadır. Ana bölümde ekollerin yaklaşımları, ilâhî sıfatlar ve insanın etkinliği şeklinde iki açıdan incelenmiş, sonuç kısmında tartışmaların ardındaki ortak kanaatler tespit edilmeye çalışılııştır.

Anahtar Kelimeler: Kelâm, İslam teorik düşünce ekolleri, İlâhî sıfatlar, İnsan fiilleri, Sorumluluk, Kötülük, Ortak düşünce. 


\begin{abstract}
The subject of human acts has been one of the controversial topics of kalām since the first centuries of Islam. A lot of concerning human acts -from divine attributes to divine decree and destiny, from the issue of good and evil (husn and Qubh) to the boundaries of the reasoning, from the accountability with impossible things to the rational accountability, from the topics of substance and accident to causality- has been said and written in the history of Islamic tought. In this study, the subject was discussed especially within the scope of man's on his own action in connection with the divine knowledge, will, and power. On this issue, the Mu'tazila argues that human beings are independent in doing their good and evil acts with the power that God has given to them because of His will and wisdom, and that the evil actions that they have done cannot be associated with the divine attributes in any way. Sunni theologians assert that God creates human actions through man's orginated power. They also arguethat evil acts are not independent of the Divine Creation although human beings are the reason of evil in terms of thier acquisition (kasb) and will (iräda). Nevertheless, the representetives of the Sunnī kalām (Asharites and Māturīdis) differ on their account of acquisition, which expresses man's agency in his acts. In contrary to the Mātūindiya, the Ash ariya holds that acquisition is a created act of God. On the other hand, the Mashshai (peripatetic) philosophers, who are opposed by teologians on some issues such as divine attributes and the working of activity/acts in nature, consider human's actions part of the eternal chain of cause-effect that emanate (al fayd) from the First Principle. However, according to them, every link of this chain is formed by the divine providence (al-ināyah). They also attribute morally evil acts not to the First Principle which is complete (tām) and full good (hayr), but to agents in the cause-effect chain. In summary, according to both teologians and philosophers, the ultimate source of human acts is the divine will and power. The acts that are morally or religiously evil, are not independent of man's will. Thus, human beings are accountable for their actions. Philosophers and teologians, who agree on these issues, have explained their views and build their opinions on different concepts and principles. They have shown a very different attitude in their discourse and secondary principles, while all of them basically try to express the same idea. This difference has revealed within the frame of the following questions: Is man's accountability for his actions because of his created power or will? Can evil actions, which are willed by human beings and therefore created by God, attributed to Him? Does the fact that the world emanates from God, the First Principle, due to His knowledge and essence, necessitate Him to be a willess and ineffective agent, and therefore to be a cause cause that has no effect on man's actions? Although teologians and philosophers have put forward different views in the context of the answers to these questions, they agree on the issues we have mentioned above. As this study shows, there is actually a common purpose in this subject, man's actions, which causes deep divisions between theologians and philosophers in Islamic history. Primary sources of the study are the basic texts of the schools mentioned above. Additionally, the study were limited to the subject the effect of human on acts. It consists of two parts: the main part and the conclusion part. In the main section, the approaches of schools were examined from two aspects, in in terms of divine attribute and human effectiveness, and in the conclusion section, the common purposes behind the discussions were determined.
\end{abstract}

Keywords: Kalām, Islamic theoretical thought schools, Divine attributes, Human acts, Accountability, Evil, Common purpose. 


\section{Giriş}

Doğanın, insanı düşüncelerinde ve eylemlerinde kuşatan, güdüleyen ve arzuları ile imkânları arasındaki ikilemde sınırlayan yapısı ile yaratıcının mutlaklı̆̆ı ve bağımsızlığı göz önünde bulundurulduğunda, insanın, fiilleri üzerinde etkin olup olmadığı meselesinin, doğada bir varlık olarak insanın doğal çevresi ile irtibatından ve yaratıcı karşısındaki konumunun mahiyetini araştırmasından kaynaklandığı söylenebilir. Dolayısıyla bu meselenin düşünce tarihinin hemen bütün evrelerinde ve temsilci öğretilerinde bir mesele olarak ele alındığı ileri sürülebilir. Nitekim semâvî dinlerden klasik ve güncel beșerî akımlara kadar hemen bütün düşünce ekollerinde bu mesele muhtelif bağlamlarda konu edinilmiştir. İslam teorik düşünce geleneğinde $\mathrm{Mu}$ 'tezile, Mâtürîdî ve Eş̧arî kelâm ekollerinin yanı sıra felsefenin de temel meseleleri arasında yer alan insan fiilleri kelâm ilminin pek çok konusu ile irtibatlıdır. Bunlar arasında Allah'ın sıfatlarının insan üzerindeki etkileri, insanın kötü fiillerinin Allah'a nispet edilmesi, eşyada doğal zorunluluğun varlığı ya da yokluğu, insanın sorumluluğunun zemini, akla bağlı sorumluluk (teklîfi aklî), gücün yetmediği şeyle sorumlu tutulma, cebir ya da iradîliği ima eden dinî metinlerin yorumlanması, eşyanın doğasında iyilik ve kötülüğün bunup bulunmadığı, kaza ve kader, ecelin tayini ve rızık gibi konular zikredilebilir. Belirtmek gerekir ki, insan fiilleri meselesi, adı geçen hemen bütün ekol ve disiplinlerde farklı kavram, yorum ve ilkelere bağlı kalınarak açıklanmıştır. Böylece insan fiilleri meselesinde, kelâm ekolleri arasında ve kelâmcilar ile felsefeciler arasında, zaman zaman dışlayıcı bir üslup içerisinde dile getirilen, söylem farklılıkları ortaya çımıştır. $\mathrm{Bu}$ söylem farklılıklarının ortaya çıkışının ve derinleşmesinin siyasi, sosyal ya da dinî sebeplerinin incelenmesi bu çalışmada ele alınmamıştır. Şimdi, bu söylemlerin ardında Allah, insan ve fiil ilişkisine dair söylenmek istenen esas maksat ve mânaların kesin bir biçimde birbirlerinden ayrıştıkları ileri sürülebilir mi? Başka bir ifade ile bu ekollerin insan fiilleri kapsamında ortaya koydukları, diğerleri ile çatışan söylemlerinin ardında -birbiri ile örtüşen- söylenmek istenen ortak bir amaç ve anlam var mıdır? Çalışmamızın merkezinde yer alan soru budur. Ana bölüm ve değerlendirme şeklinde iki kısımdan oluşan çalışmamızın ana bölümünde bu soruların cevaplarını tartışmaktan kaçındık. Ana metinde yalnızca, anılan ekollerin insan fiillerine ilişkin yaklaşımlarını inceledik. Sonuç ve Değerlendirme başlı̆̆ı altında ise ana bölümde serdedilen değerlendirmelerden hareketle düşünce ekollerinin ortak ve hemfikir oldukları hususlar/önermeler tespit edilmeye çalışılmıştır. Ekollerin yaklaşımları incelenirken, muhtelif kelâmî ve hukukî konular ile ilişkili olan insan fiilleri meselesini, azami ölçüde, 'Allah'ın sıfatlarının kuşatıcılığı karşısında insanın, fiilleri üzerindeki etkisinin ne olduğunun tespiti' sorunu ile sınırlı tutmaya çalıştık. İncelemede öncelikle, ekollerin Allah'ın ilim, irade ve kudret sıfatları ilgili ilgili değerlendirmeleri insanın fiilleri ile ilişkisi bağlamında ele alınmış akabinde insanın fiil üzerindeki etkisinin mâhiyeti tartışılmıştır. Bu bağlamda ekollerin karşıt görüşlerle tartışmaları ve bu tartışmalarda kullandıkları deliller çalışmanın makul sınırlarını zorlayacağı için polemikçi bir anlatım ve aktarımdan kaçınılmış, çalışmada, temelde, ekolleri birbirinden ayrıştıran yönlerin, iddiaların ve anlatım biçimlerinin öne çıkarılması hedeflenmiştir. Çalışmada teorik düşünceyi yöntem olarak belirleyen yaygın kelâm ekolleri Mưtezile, Mâtürîdîlik ve Eşsarîlik ile kelâmcıların sıklıkla atıfta bulundukları ve eleştirdikleri İbn Sînâcı felsefe geleneğine yer verilmiştir. Çalışmanın temel hedefi, insan fiilleri meselesinde klasik dönemde yapılan 
tartışmaların arka planında, ortak amaçların -en azından tartışmalarda tezahür eden söylemler kadar dışlayıcı ve derin olmayan ortak paydaların- yer aldığı düşüncesini öne sürmektir.

\section{Mu'tezile'de İnsan Fiilleri}

Mu'tezile, dış kültürlerle etkileşimler, iç buhranlar ve siyasî sâiklerle Müslümanlar arasında varlık bulup yaygınlaşan ve insanın, ilâhî kudretin ve tabiî sebeplerin etkisinde kalmadan, eylemlerinde etkin olduğunu ifade eden "kaderî" düşünceyi benimsemiş ve bu düşünceyi kendi bünyesine tutarlı bir şekilde eklemlemiştir. Burada insan fiilleri konusu çerçevesinde Mu'tezile'nin sıfatlar ve insanın kudretine ilişkin görüşlerini ele alacağız. Öncelikle irade sıfatıyla başlayacağız. Mu'tezile'de Allah'ın "mürîd" (irade eden) bir fâil olduğu genel olarak kabul edilse de bu sifata yüklenen anlam, mezhep içerisinde tartışılmıştır. Kâbî (öl. 319/931), Nazzâm (öl. 231/845), Câhız (öl. 255/869) ve Neccâr (öl. 230/845 civarı) iradeyi, belli bir fiili ve vaktini tayin etmek anlamındaki anlamıyla Allah'a nispet etmekten kaçınırken, Ebü’l-Hüzeyl el-Allâf (öl. 235/849-50), Kādî Abdülcebbâr (öl. 415/1025) ve Zemahşerî (öl. 538/1144) gibi isimler Allah'ın bu anlamda irade sahibi olduğunu kabul ederler. ${ }^{1}$ Ancak onlar iradeyi Eş'arî ve Mâtürîlîler'de olduğu gibi ezelî bir sıfat olarak değerlendirmeyip bir mahalde (araz ya da niteliğin gerçeklik zemini) yer almayan ve yaratılan şeyden hemen önce (lahza) var olan hâdis ve fiilî bir sıfat kabul ederler. ${ }^{2}$ Allah'ın hakikî anlamda mürîd olduğunu savunan Mu'tezile kelâmcıları, O'nun iradesini iki şey ile sınırlandırırlar. Bunlar kullardan sâdır olan mübâh fiiller ile ilâhî rızâya konu olmayan kötü (kabîh) fiillerdir. ${ }^{3}$ İrâdenin bu şekilde sınırlandırılması Mu'tezile'nin ilâhî fiiller anlayışı ile ilgilidir. Mu'tezile Allah'ın, âdil ve hakîm sıfatları gereğince kötü olan bir şeyi irade etmeyeceğini ve yapmayacağını savunur. Kādî Abdülcebbâr bu durumu şöyle açıklar: "Ezelî olan Allah Teâlâ'yı adl ve hakîm diye nitelediğimizde, bununla O'nun kötü olan bir şeyi yapmayacağı ve irade etmeyeceği kastedilir. [...] O’nun bütün fiilleri güzeldir. [...] Bunun delili şudur şudur: 0 , kötünün kötülüğünü bilir ve ona

Nazzâm, Allah'ın kendi fiilini irade etmesini yaratma, insanların fillerini yaratasını emir anlamında değerlendirirken, O'nun ezelî olarak mürîd olmasını, ezelî planda âlim olması şeklide yorumlamaktadır. Neccâr'a göre mürîd sıfatı, Allah'ın başka bir güç altında kalmadığını ifade ederken, Câhız insanların ve Allah'ın mürîd olduğunu büsbütün reddetmekte, fâilin, meylederek bir işi yapmasının aynı zamanda onun iradesini de kapsadığını ve âlim olmanın mürîd olmayı ifade ettiğini söylemektedir. Bu görüşlere mukabil Allah'ın hakikî anlamda mürîd olduğunu ileri süren Mu'tezile kelâmcıları, şâhid (fizikî) gerçeklikte bir işin belli bir şekilde ve belli bir zamanda olması mümkünken başka bir şekilde ve zamanda olmasını sağlayan şeyin irade olduğunu ve bu durumun ğaib (ilâhî) gerçeklik için de geçerli olduğunu söyleyerek Allah'ın irade sahibi olduğunu savunurlar. Kādî Abdülcebbâr, Şerhu'lUsûli'l-hamse, ta'lîk, Ahmed b. el-Hüseyin Mânkdîm, thk. Abdulkerim Osman (Kahire: Mektebetü Vehbe, 1996), 431434; Zemahşerî, el-Minhâc fí usûli'd-dîn, thk. Abbas Hüseyin (San 'â: Mektebetü Merkezi Bedri'l-'İlmî, ts.), 9; Zemahşerî, Mu'tezile Akaidi Kitabü'l-Minhac fì usûli'd-dîn, çev. Ulvi Murat Kılavuz - A. İskender Sarıca (ìstanbul: Klasik Yayınları, 2021); Şehristânî, Nihâyetü'l-ikdâm fì 'ilmi'l-kelâm, nşr. Alfred Guillaume (Kahire: Mektebetü's-Sekāfeti'd-Dîniyye, 2009), 227-228.

2 Kādî Abdülcebbâr, Şerhu'l-Usûli'l-hamse, 431, 447-448; Şehristânî, Nihâyetü'l-ikdâm, 136. Mu'tezile'de kudret kavramı ile ilgili geniş bilgi için bk. Yunus Cengiz, Mu ‘tezile'de Eylem Teorisi Kādî Abdülcebbâr Örneği (İstanbul: Düşün Yayıncılık, 2012), 115-138.

3 Kādî Abdülcebbâr, Şerhu'l-Usûli'l-hamse, 457-459. Buna karşın Mu'tezile, Allah'in, insanların iyi fiillerini irade ettiğini kabul etmektedir. Ancak onlara göre Allah'ın iyi fiilleri irade etmesi iyi olanı yapmaya ya da kötüden kaşınmaya zorlayan bir irade değil, iyinin seçilmesini, tercih edilmesini isteyen iradedir. Kādî Abdülcebbâr, el-Muğnî/Irâde (Kahire: y.y., ts.), 6-2/316. Mu'tezile'de ilâhî iradenin sinırlanması ile ilgili olarak bk. Veysi Ünverdi, "Kādi Abdulcabbâr'da Allah'ın İrâdesinin Sınırlandırılması”, şırnak Üniversitesi İlahiyat Fakültesi Dergisi 3/5 (01 Haziran 2012), 107-126. 
ihtiyacı da yoktur (müstağnî) ayrıca O, kötüye ihtiyacı olmadığını da bilir. İşte bu durumda olan kişi, hiçbir şekilde kötü olanı irade etmez." ${ }^{\prime 4}$ Görüldüğü üzere burada ilim, irade, kudret, adl ve hikmet sıfatları birlikte değerlendirilmişlerdir. Bu nedenle insan fiilleri bağlamında bu sıfatları birbirleriyle bağlantılı olarak ele almak uygun olacaktır.

Mu'tezile kelâmcıları genel olarak, Allah'ın, gelecek de dahil olmak üzere bütün şeyleri/fiilleri ezelî olarak bildiğini savunurlar. ${ }^{5}$ Bununla beraber Mu'tezile'den bazıları, Allah'ın ezelî bilgisini, insanın fiilini zorunlu kıldığını ve teklîfi anlamsız hale getirdiğini ileri sürerek reddederler. Ebü'lHüseyin el-Basrî (öl. 436/1044) bu eleştiriye, Allah'ın bilgisinin kulun fiilini zorunlu kılmadığını ve Allah'ın, şeyleri kulun irade ve kudretine münâsib olarak bildiğini, dolayısıyla Allah'ın bilgisinin, bilinen fiili zorunlu hale getirmediğini söyleyerek cevap verir. ${ }^{6}$ Mu'tezile kelâmcıları Allah'ın kudretinin de ilim sıfatı gibi ezelî olduğunu, O’nun ezelî ve ebedî bütün fiillere kādir olduğunu, hiçbir türdeki ve sayıdaki fiilin O'nun kādirliğini sınırlamayacağını savunurlar. ${ }^{7}$ Ali el-Esvârî (öl. 240/854), Nazzâm ve Câhız gibi bazı istisnalar olmakla birlikte Mu'tezile kelâmciları Allah'ın kudretinin -kötü fiilleri kapsayacak yeterliliğe sahip olması anlamında- yaratmaya kādir olduğunu, savunurlar. ${ }^{8}$ Kādiri, fiili meydana getiren, ${ }^{9}$ fiili ise kādirin var ettiği şey/fiil olarak ${ }^{10}$ değerlendiren Mu'tezile kelâmcıları, bütün fiilleri kapsama imkânı olsa da Allah'ın kādirliğini, "fâilin yaptığı her iyi fiil" ${ }^{11}$ şeklinde tanımlanan adâlet sıfatı ile birlikte değerlendirdikleri için ilâhî kudretin yalnızca, insana nispet edilen fiillerin dışındaki iyi fiiller ile sınırlı olduğunu kabul ederler. Buna göre insanların kötü ve iyi fiilleri Allah'ın kādirliğinin kapsamından çıkmaktadır. İnsanın kötü fiilleri ilâhî kudretin kapsamında değildir, çünkü ilâhî kudret -kötüyü yaratmak için yeterli olsa da- kötü olana tealluk etmez. ${ }^{12}$ İnsanların iyi fiilleri ise, onların bu fiillerle sorumlu kılınmaları nedeniyle kādirliğin kapsamından çıkmaktadır. ${ }^{13}$ Zira insanın, kendi fiilinin kādiri olmaksızın sorumlu tutulması onu gücü yetmeyen şeyle sorumlu tutmak (teklifi mâ lâ-yutâk) anlamına gelir ki, böyle bir sorumluluk verme (teklîf) Mu'tezile kelâmcıları tarafından kötü kabul edilmiş ve Allah'in insana bu şekilde sorumluluk vermesi reddedilmiştir. ${ }^{14}$ Allah Teâlâ ise kötü olan bir şeyi yapmaz. O yalnızca hikmeti ve doğruyu/iyiyi (savâb) irade eder. ${ }^{15}$ Kādî Abdülcebbâr,

Kādî Abdülcebbâr, Şerhu'l-Usûli'l-hamse, 301, 302.

Kādî Abdülcebbâr, Şerhu'l-Usûli'l-hamse, 160; Ebü'l-Hüseyin el-Basrî, Tesaffuhu'l-edille, nşr. Wilferd Madelung (Wiesbaden: Harrasowitz Verlag, 2006), 59-65.

6 Ebü'l-Hüseyin el-Basrî, Tesaffuhu'l-edille, 116, 120; Albert Nasrî Nâdir, Felsefetü'l-Mu'tezile (İskenderiye: Matbaatu Dârü Neşri's-Sekāfe, 1950), 67.

Kādî Abdülcebbâr, Şerhu'l-Usûli'l-hamse, 155-156; Ebü'l-Hüseyin el-Basrî, Tesaffuhu'l-edille, 77.

Kādî Abdülcebbâr, Şerhu'l-Usûli'l-hamse, 313; Ebü'l-Hüseyin el-Basrî, Tesaffuhu'l-edille, 89.

Kādî Abdülcebbâr, Şerhu'l-Usûli'l-hamse, 151.

Kādî Abdülcebbâr, Şerhu'l-Usûli'l-hamse, 324.

Kādî Abdülcebbâr, Şerhu'l-Usûli'l-hamse, 301.

Kādî Abdülcebbâr, Şerhu'l-Usûli'l-hamse, 357.

Kādî Abdülcebbâr, Şerhu'l-Usûli'l-hamse, 316.

Kādî Abdülcebbâr, Şerhu'l-Usûli'l-hamse, 332, 345, 396; Kādî Abdülcebbâr, el-Muhtasar fî usûli'd-dîn (Resâilu'l'adl ve'ttevhîd), thk. Muhammed Ammâre (Kahire: Darü'ş-Şurûk, 1988), 238; Cuşemî, Tahkîmu'l-'ukūl fî tashîhi'l-usûl (San'a: Müessesetü'l-İmam Zeyd b. Ali, 2002), 115.

15 Kādî Abdülcebbâr, el-Muhtasar, 232; Kādî Abdülcebbâr el-Muhtasar'da Allah Teâlâ'nın, hayrı/tâati irade ederek peygamberler gönderdiğini ve insanların onlara tâbî olmalarını irade ettiğini; O’nun iradesinin zorunlu kılıcı bir irade olduğunu, bu durumda O'nun insanların kötü fiillerini irade ettiğini söylemenin abes/hikmetsiz olacağını söylemektedir. el-Muhtasar, 228. 
adâlet ilkelerine ayırdığı başlık altında ele aldığı kudretin insan fiillerinden önce olduğunu söyledikten sonra kudretin adâletle ilişkisi şöyle kurmaktadır: "Bu konunun adâlet ile ilişkisi şudur: Kudret fiil ile birlikte olsa insanı gücü yetmeyen şeyle sorumlu tutma (teklifi mâ lâ-yutâk) sorunu ortaya çıkar. Bu ise çirkindir. Adâleti gereği Allah çirkin olanı eylemez."'16

Allah'ın âlim, mürîd, kādir, adl ve hakîm sıfatları hakkındaki bu mütalaaları ile mutabık olarak Mu'tezile kelâmcıları, insanın kudrete fiilinden önce sahip olduğunu ve insanın, kendi fiillerinin kādiri ve fâili olduğunu kabul ederler. Bu çıkarımı açıklamak amacıyla burada iki tasnife yer vermek istiyoruz. Birincisi Kādî Abdülcebbâr'ın fiillerle ilgili tasnifidir. Bu tasnife göre fiiller, insanın kudreti kapsamında olanlar ve olmayan şeklinde iki kısma ayrılmaktadır. Cevherler, renkler, tatlar, kokular, kudret, arzular, nefretler gibi fiiller, insanın değil, Allah'ın kudreti ve fiilleri kapsamındadır. İnsanın fiilleri ise uzuvların (ef âl-i cevârih) fiilleri ve kalbin fiilleri (efâl-i kulûb) olmak üzere iki kısma ayırır. İlki, oluş, itme, bileşim, ses ve elem şeklinde ve ikincisi inanç, irade, nefret, zan ve fikir şeklinde beşer kısımdan oluşmaktadır. ${ }^{17}$ İkinci taksim ise İbn Metteveyh'in (öl. V./XI. yüzyılın ortaları) arazlarla ilgili aktardığı taksimdir: Bu taksime göre, arazlar sürekli olanlar ( $m a \hat{~ y e b k a ̄) ~ v e ~ s u ̈ r e k l i ~ o l m a y a n l a r ~(~} m a \hat{a} l \hat{a}-y e b k \bar{a})$ şeklinde iki kısma ayırırlar. İbn Metteveyh renkler, tatlar, kokular, sıcaklık, soğukluk, yaşlık, kuruluk, hayat, kudret, oluşlar ve bileşimler gibi arazların sürekli olduklarını ve bunların dışında kalanların ise sürekli olmayıp, an be an yaratıldıklarını belirtir. ${ }^{18}$

Fiiller ve arazlar üzerine yapılan bu taksimler muvacehesinde şunlar söylenebilir: Kudret, Mu'tezile kelâmcılarına göre doğrudan Allah tarafından insanın bedeninde yaratılan ve insanın fiillerinden önce kendisinde mevcut olup onun iyi ya da kötü bütün fiillerini yapabilmesine imkânı veren bir arazdır, sıfattır. ${ }^{19}$ İnsan, kendisinde yaratılan ve varlığı sürekli olan kudret arazı ile kendi fiillerini irade etmekte ve meydana getirmektedir. Mu'tezile insanın fiili üzerindeki etkinliğine ilişkin bu iddiasını Kādî Abdülcebbâr'ın "güvenilir yöntem” dediği şu delil ile takviye eder: İnsanlar fiillerini, bütün etkenler salimen hazır olduklarında, güdüleri (devâ̂̀) ve iradeleri ile gerçekleştirirler. İnsanın fiili eğer doğrudan Allah'ın kudreti ile meydana geliyorsa, bu durumda insanın güdü (dầ $\hat{\imath})$ ve iradesinin fiil üzerinde bir etkisi yoktur, dolayısıyla insanın, irade, inanç vs. gibi yetilere de ihtiyacı olmaz. ${ }^{20} \mathrm{Bu}$ delile göre fiili gerçekleştirme güdü ve iradesi kime ait ise kudret de ona ait olmalıdır. Başka bir ifade ile yaptığı fiillerin insana nispet edilmesinin sebebi bedenî yeterliliklerin sağlamlığı ve diğer engellerin bulunmaması koşuşuyla- onun irade ve güdüsünün fiil üzerinde etkin olmasıdır. Kādî Abdülcebbâr, bir güdü insanı kalkmaya ya da yemeye güdülediğinde kalkma ya da yeme eyleminin gerçekleșeceğini, kula ait fiillerin irade ve

Kādî Abdülcebbâr, Şerhu'l-Usûli'l-hamse, 390.

Kādî Abdülcebbâr, Şerhu'l-Usûli'l-hamse, 90.

18 İbn Metteveyh, et-Tezkire fí ahkâmi'l-cevâhir ve'l-a'râz, nşr. İbrahim Medkûr (Kahire: Dârü's-Sekāfe, ts.), 41. Arazlarla ilgili geniş bilgi için bk. Mehmet Bulgen, Kelâm Atomculuğu ve Modern Kozmoloji (Ankara: TDV Yayınları, 2018), 199206.

19 Kādî Abdülcebbâr, bu bağlamda, fiilden önce kulda bulunan kudretin, döven ya da sadaka veren "el" gibi, bir mümini haksız yere öldürmek ya da düşmanları öldürmek için kullanılan "bıçak" gibi bir âlet gibi olduğunu kaydeder. elMuhtasar, 246.

20 Kādî Abdülcebbâr, Şerhu'l-Usûli'l-hamse, 53, 336; Ebü'l-Hüseyin el-Basrî, Tesaffuhu'l-edille, 24; Cuşemî, Tahkîmu'l- ‘ukūl, 120; Orhan Ş. Koloğlu, Cübbailer'in Kelâm Sistemi (İstanbul: İSAM Yayınları, 2017), 171-185. 
güdüye, maddi araçların/uzuvların sağlamlığına, kulun varlığından önceki sebeplerin varlığına bağlı olduğunu söyler. ${ }^{21}$

$\mathrm{Bu}$ bakış açısı, Mu'tezile'de, fiilden önce olduğu kabul edilen kudretin, araçların sağlamlığı (selâmetü'l-esbâb) anlamında kullanıldığını ima etse de, bir araz olarak kudretin fiilden önce insanda mevcut olduğu görüşü, onlara göre kudret, bu imanın içerdiğinden daha fazla bir anlama ve etkinliğe sahiptir. ${ }^{22}$ Nitekim Kādî Abdülcebbâr da fiillerin insana ihtiyaç duyduklarını, dolayısıyla insanın fiiller üzerinde etkin olduklarını ve bu etkinin, varlığın ortaya çıkması (hudûs ve teceddüd) noktasında gerçekleștiğini söylemektedir. ${ }^{23}$

Belirtmek gerekir ki, Mu'tezile insanın, fiilinin fâili olduğu söylerken tabiatta Allah'ın kudretinden bağımsız güçlerin bulunduğunu, insanın kudretinin de bu çerçevede değerlendirilmesi gerektiğini ileri sürmemektedir. Ya da en azından böyle bir değerlendirme, mezhebin genel yaklaşımını yansıtmamaktadır. Muammer b. Abbâd (öl. 215/830), Câhız ve Nazzâm gibi bazı Mu'tezile kelâmcıları Allah'ın tabiata bazı özellikler verdiğini ve eşyânın zorunlu olarak bu tabiî özelliklerine bağlı kaldıklarını savunurlar. ${ }^{24}$ Buna mukabil Ebü'l-Hüzeyl, Cübbâîler, ${ }^{25}$ Kādî Abdülcebbâr, ${ }^{26}$ Ebü'l-Hüseyn el-Basrî (öl. 436/1044), Cuşemî (öl. 494/1101) ${ }^{27}$ ve İbnü'l-Melâhimî (öl. 536/1141) ${ }^{28}$ gibi kelâmcılar "sürekli yaratma" (halk-ı müstemirr) düşüncesine bağlı kalarak zorunlu sebepliliği reddederler. ${ }^{29} \mathrm{Bu}$ konuda onların temel sâikinin Allah'ın kudretinin sınırlandırılması endişesi olduğunu söylemek mümkündür. Nitekim bu geç dönem Mu'tezile

21 Kādî Abdülcebbâr, Şerhu'l-Usûli'l-hamse, 337.

22 Bununla beraber, Eş‘arî, Bişr b. Mutemir ve Sümâme b. Eşres gibi bazı Mu'tezile kelâmcılarının kudreti, uzuvların sağlamlığı ve engellerin yokluğu anlamında değerlendirdiklerini nakleder. Eş‘arî, Makālâtü'l-İslâmiyyîn, nşr. Hellmut Ritter (Wiesbaden: Franz Steiner Verlag, 1980), 229.

23 Kādî Abdülcebbâr, Şerhu'l-Usûli'l-hamse, 118-119; Cuşemî, Tahkîmu'l-'ukūl fî tashîhi'l-usûl, 157-158.

24 Muammer b. Abbâd es-Sülemî, Allah'ın yalnızca cevherleri ve cevherlerdeki tabiî mânaları (doğal nitelikler) yarattı̆̆ını ve hastalık, sağlık, ölüm, dirilme, renkler ve tatlar gibi arazların ve fiillerin cisimlerdeki özellikler tarafından sebep-sonuç ilişkisi ile meydana geldiklerini savunur. Nazzâm, eşyanın özelliklerinin cismin özünde evvelemirde bilkuvve yaratıldıkları (kumûn), daha sonra yine cismin bulunduğu yer gibi doğal sebeplerin etkisiyle ortaya çıktıkları (zuhûr) şeklindeki düşüncesi ile bağlantılı olarak eşyânın doğrudan Allah'ın müdahalesi ile değil, kendi tabiatı ile fiili gerçekleştirdiğini iddia eder. Câhız da eşyanın değişmez kanunlara bağlı olduklarını, tabiatın bu kanunlara bağlı kalarak dönüşüm (istihâle) geçirdiklerini ve insanın da bu kanunlardan bağımsız olmadıklarını söyler. İslam düşüncesinde doğal sebepliliği (tabîat) savunan ilim adamlarının görüşlerinin genel bir değerlendirmesi için bk. Osman Demir, Kelâmda Nedensellik İlk Dönem Kelâmcılarında Tabiat ve İnsan (İstanbul: Klasik Yayınlar1, 2015), 101-122.

25 Eş'arî Makālât'da her iki ilim adamının, ağır taşın taş havada düşmeden kalacağını, ateşin pamuk ile yanmadan beraber bulunabileceğini mümkün gördükleri aktarır. Ayrıca Ebü'l-Hüzeyl, Allah'ın, âmâ bir kimsede renklerin idrakini yaratmasının ya da herhangi bir engel bulunmadığında gözde görme idrakini yaratmamasının mümkün olduğunu söyler. Eş'arî, Makālât, 312, 569; Orhan Ş. Koloğlu, Cübbailer'in Kelâm Sistemi, 158.

26 Kādî Abdülcebbâr, irade sahibi fâilin dışında, fiili zorunlu kılan illet anlamında tabiat, nefis, akıl ve yıldızlar gibi müessirleri makul bulmadı̆̆ını söyleyerek reddeder. Kādî Abdülcebbâr, Şerhu'l-Usûli'l-hamse, 120-122, 325.

27 Cuşemî, Tahkîmu'l-'ukūl, 68-80.

28 Melâhimî, Tuhfe ve el-Fâik adlı eserlerinde de tabiattaki olayları zorunlu illet-malûl ilişkisi içinde değerlendiren felsefecilerin yaklaşımlarını eleştirmektedir. Melâhimî, Tuhfetu'l-mütekellimîn fi'r-reddi ale'l-felâsife, thk. Hassan Ansarî (Tahran: Iranian Institute of Philosophy, 2008), 130-135; Melâhimî, Kitâbu'l-fâik fì usûli'd-dîn, thk. Faysal Bedîr Avn (Kahire: Dârü'l-Kütüb ve'l-Vesâiki'-Kavmiyye, 2010), 146-150; Orhan Ş. Koloğlu, Mu'tezile'nin Felsefe Eleştirisi Harezmli Mu'tezili İbnü'l-Melâhimînin Felsefeye Reddiyesi (Bursa: Emin Yayınları, 2010), 288-297.

29 Genel bir değerlendirme için bk. Munâ A. Ebu Zeyd, et-Tasavvuru'z-zerrî (Beyrut: el-Müessesetü'l-Câmi'iyye, 1994), 259-269. 
kelâmcıları âlemde sebeplilik ilkesinin zorunlu olmadığını söyleseler de mutlak anlamda sebepliliği reddetmemekte, bilakis Allah'ın fâil-i muhtâr olması ve kudretinin sınırlanmasından kaçınmak için sebeplerin zorunlu olmadığını savunmaktadırlar. Nitekim Ebü’l-Hüzeyl ve Cübbâî'de görülen cevâz teorisi, ${ }^{30}$ Kādî Abülcebbâr'ın, Allah'ın sebebi yaratıp sonucu (müsebbeb) yaratmamasının mümkün olduğunu söylemesi ${ }^{31}$ ve bütün cisimleri ve arazları yaratının fâil-i muhtâr olan Allah olduğunu ortaya koyduktan sonra zorunlu tabiat görüşünü eleştirmesi, Cüşemînnin eşyâdaki olayları tabiata nispet edenlere karşı bütün bunların irade sahibi bir fâil tarafından var edildikleri tezini savunması, Melâhimînnin felsefecilerin tabiattaki doğal süreçleri sebep-sonuç ilişki içerisinde açıklayan yaklaşımlarını özetledikten sonra "Bütün bunlar, onların zorlamalarıdır. Bu zorlamalar ile onlar, zikrettikleri bütün olayları kendi iradesi ile kullarına ihsânda bulunmak için yaratan irade sahibi yaratıcıyı (es-Sâni 'u'l-Muhtâr) reddetmişlerdir (def')" demesi ve akabinde Allah'ın her şeyi yarattığını anlatan ayetlere yer vermesi bu kanaati desteklemektedir.

Neticede olarak şu söylenebilir: Mezhep içinde farklı görüşleri savunanlar bulunsa da, Allah'ın âlimliğinin ve kādirliğinin bütün mevcûdâtı kapsadığı, tabiattaki bütün fiillerin Allah'ın kudreti ile meydana geldiği, teklîfin makul bir zemine oturtulması amacıyla insanlara ait olduğu savunulan ve bir araz olan kudretin Allah tarafından onlara verildiği ve insanının, irade ve güdüsü ile bu kudreti kullanarak fiillerini icra ettikleri düşüncesi, Mu'tezile'de -özellikle son dönem temsilcilerinde- kabul gören genel yaklaşımı yansıtmaktadır.

\section{Mâtürîdî ve Eş‘arî Düşüncede İnsan Fiilleri}

Farklı iklim ve ilim havzalarında neşet eden Mâtürîdî ve Eş‘arî mezhepleri, usûlüddînin meselelerinde büyük oranda hemfikir olsalar da bazı meselelerde, aralarında fikir ayrilığı bulunmaktadır. İnsan fiilleri konusu da belli bir açıdan da olsa fikir ayrılı̆̆ı yaşanan bu meseleler arasında yer almaktadır. Burada her iki ekolün konuya dair müttefik oldukları temel kabulleri ve akabinde ayrıştıkları noktaları ortaya koymaya çalışacağız. İnceleme konumuz itibarıyla temel meselelerde hemfikir olmaları nedeniyle Mâturîdî ve Eş'arî ekollerini aynı başlık altında incelemeyi tercih ettik. İki ekol arasındaki tartışmalı olan bazı hususları yine konumuz ekseninde kalmaya özen göstererek açıkladık.

Doğrudan tabiat ve insan fiilleri ile ilgili ilâhî sıfatlar olan ilim, irade ve kudretin sıfatlarının, ezelî ve her şeyi kuşattıklarını her iki ekol kabul etmektedir. Buna göre var olan ve olacak olan her şey doğrudan Allah'ın bilgisi kapsamında ve O'nun irade ${ }^{32}$ ve kudreti ile meydana gelmektedir. Onun kudretinden başka eşya üzerinde var edici hiçbir güç ve fâil yoktur. ${ }^{33}$ Burada birkaç husus söz

\footnotetext{
Eş'arî, Makālât, 312, 569.
}

Kādî Abdülcebbâr, Şerhu'l-Usûli'l-hamse, 389-390.

32 Burada iradeyi muhabbet ve rızâ ile birlikte değerlendiren bazı Eş‘arîlerin yaklaşımları, Allah'ın kötü fiilleri severek irade etmesi şeklinde anlaşılabileceği için mahzurlu bir konum arz ediyor gibi gözükmektedir. Ancak Cüveynî bu yaklaşımı şöyle yorumlamaktadır: "Allah Teâlâ, kulun küfrüne [ve kötü fiillerine] onları cezalandıracak olması yönüyle râzı olur.” Cüveynî, el-İrşâd, thk. Muhammed Yusuf Musa (Mısır: Mektebetü'l-Hâncî, 1950), 239. Bu yoruma göre ilâhî rızânın iyi ve kötü fiillere yönelişi farklı açılardandır. İlkine gerçekleşmesi açısından, ikincisine ise gerçekleştiğinde adâletle karşılığının görülecek olması açısındandır.

33 Eş'arî, el-Luma' fi'r-reddi alâ ehli'z-zeyi ve'l-bida', nşr. Hammûde Gurâbe (Kahire: Matbaatu Misriyye, 1955), 25, 47; Cüveynî, el-İrşâd, 187; Şehristânî, Nihâyetü'l-ikdâm, 206; Bâkıllânî, Temhîdü'l-evâil ve telhîsü'd-delâil (Beyrut: 
konusudur. Birincisi, Allah'ın ezelî ilminin, hâdis zamanda gerçekleşen olayları zorunlu kılıp kılmayacağı sorunudur. Her iki mezhep de -Mu'tezile'de olduğu gibi- ezelî ilmin malûma/olaya tâbi olduğu ilkesine istinaden ilmin bilinen olayı zorunlu kılmadığını kabul eder. ${ }^{34}$ Dolayısıyla Allah'ın ilmi herhangi bir şekilde bilinen olayı etkilemediği için, mezkûr sorun etkisini kaybedecektir. Diğer husus ise Allah'ın hayır ve şerri, iyi ve kötüyü irade etmesinin, kötülügün O’na nispet edilmesini gerektirip gerektirmeyeceği meselesidir. İmam Mâtürîdî (öl. 333/944), Allah Teâlâ'nın her şeyi yarattığını, kötüyü yaratması nedeniyle kötülükle nitelenemeyeceğini, yaratma (halk) ile yaratma sonucu meydana gelen şeyin (halku filil'l-halk) farklı olduklarını ifade eder. Akabinde de, O'nun her şeyi hikmetine bağlı olarak yerli yerinde var ettiğini (vazáa külle şey'in mevzı'ahû) söyleyerek bunun hikmetle çelişmediğini ve zulüm olmayacağını, yedirme, giydirme ve rrzık vermenin de Allah'a ait olduğunu ancak O'nun, yeme, giyinme ve rızıklanma ile isimlendirilmeyeceğini söyler. ${ }^{35}$ İmam Eş`arî (öl. 324/935-36) de Allah'ın, kötü bir fiili başkasında/başkası için yarattığını, O'nun, bir cisimde hareketi yaratması nedeniyle "hareketli" diye nitelenemeyeceği gibi, zulmü başkasında yaratması nedeniyle zalimlik ile nitelenmemesi gerektiğini ifade eder. ${ }^{36}$ Eş‘arî kelâmının önemli temsilcilerinden Cüveynî (öl. 478/1085) de Allah hakkında fayda ve zararın kavramlarının düşünülemeyeceğini, dolayısıyla O'nun, kötü/zararlı fiilin kötülüğünü bilmesi nedeniyle onu yapmayacağını ve ona ihtiyaç duymayacağını söylemenin doğru olmadığını, kötü olan bir fiili yarattığında O'na bir zararın ilişmeyeceğini ve iyi ve kötü bütün fiillerin O'nun hakkında eşit olduğunu söyler. ${ }^{37}$ Ebü'l-Muîn en-Nesefî (öl. 508/1115) de iyi şeylerin ve inançsız kişinin inançsizlı̆̆ gibi kötü olan şeylerin Allah'ın var etmesi ile meydana geldiklerini ve kötü şeyleri var etmesinin, O'nun kötü olarak nitelenmesini gerektirmeyeceğini söyler. O inançsızlı̆̆ın, insanın eylemi (fiil) olduğunu, Allah Teâlâ'nın kulun seçimine göre o eylemi var ettiğini (îcâd) belirtir ve Allah Teâlâ'nın, hikmeti gereğince kulun kötü eylemlerini yaratmasının kötü olmadığını, dolayısıyla O'na kötülüğün nispet edilemeyeceğini ifade eder. ${ }^{38}$

Bu temel hususlarda ittifak eden Mâtürîlî ve Eşsarî mezhepleri Allah'in ezelî ve her şeyi kuşatan kudretinin insanın fiili ile ilişkisinin mâhiyetinde ihtilaf etmişlerdir. Başka bir ifade ile Allah'ın kudretinin kapsaminda olan insan kudretinin ne olduğu ve ne kadar etkili olduğu her iki ekol tarafından farklı biçimlerde izah edilmiştir. Öncelikle vurgulamak gerekir ki, her iki ekol de insanın iyi ve kötü fiillerinin tamamının Allah tarafından yaratıldığını kabul ederler. ${ }^{39}$ İzahtaki farklılık, kulun, Allah'ın yarattığı fiildeki katkısının ne olduğunun tespit edilmesi noktasında ortaya çıkmaktadır. Burada öne çıkan temel kavram hâdis kudret kavramıdır. Eş'arîlere göre hâdis

Müessesetü'l-Kütüb es-Sekāfiyye, 1987), 317; Mâtürîdî, Kitâbü't-Tevhîd, thk. Muhammed Aruçi (İstanbul: TDV İslâm Araştırmaları Merkezi (ISAM), 2017), 124-126; Ebü'l-Muîn en-Nesefî, et-Temhîd (Kahire: el-Mektebetü'l-Ezheriyye li'tTurâs, 2006), 34.

34 Şehristânî, Nihâyetü'l-ikdâm, 65, 88, 202; Fahreddin er-Razî, el-Metâlibu'l-'âliye mine'l-'ilmi'l-ilâhî, nşr. Muhammed Abdüseelam Şahîn (Lübnan: Dârü'l-Kütübi'l-'İlmiyye, 1999), 3-2/37; es-Semerkandî Şemseddin, es-Sahâifu'l-ilâhiyye (Lübnan: Dârü'l-Kütübi'l-'ilmiyye, 2007), 142, 175, 178.

35 Mâtürîlî, Kitâbü't-Tevhîd, 252-253, 259, 338.

36 Eş'arî, el-Luma', 79, 56-57.

37 Cüveynî, el-'Akidetü’n-Nizâmiyye fi'l-erkâni'l-isslamiyye, thk. Zahid Kevserî (Kahire: el-Mektebetü'l-Ezheriyye li’t-Turâs, 1992), 35-36..

38 Nesefî, Tebsıratü'l-edille fî usûli'd-dîn, thk. Enver Hamid İsa (Kahire: el-Mektebetü'l-Ezheriyye li't-Turâs, 2011), 2/925927.

39 Mâtürîdî, Kitâbü't-Tevhîd, 253; Nesefî, Tebsiratü'l-edille, 2/779. 
kudret, Allah'ın fiil anında insanda yarattığı sürekli olmayan bir arazdır. ${ }^{40}$ Eş'arîler bu hâdis kudretin herhangi bir şekilde insan fiillerinin varlık kazanmasında bir etkisinin olmadığını, her fiil anında bu kudretin Allah tarafından yeniden yaratıldığını savunurlar. ${ }^{41}$ Bâkıllanî bu düşüncenin sâikinin, insanların, fiillerinde her an Allah'ın yardımına muhtaç oldukları düşüncesinin yattığını söylemektedir. ${ }^{42}$ Fiil Allah'in her an yarattığı bu kudret ile meydana gelmektedir ki, bu durumda fiili var eden Allah'tır. Onlara göre fiil anında insanda vücûd bulan bu kudret insanın yalnızca "kesb eden" (fiil üzerinde çaba gösteren kişi) olmasına imkân vermektedir. Bu bağlamda onlar kesbi "fiilin hâdis kudret ile meydana gelmesi”"33 -ki, Eş'arî, bu tanımı tercih ettiğini söylemektedir"fiil anında fiil üzerinde, onu felçlinin hareketi gibi zorunlu bir eylem olmaktan çıaran tasarruf", 44 "kulun, [hâdis olan] irade ve kudretini fiil anında [belli bir fiile] yöneltmesi”" ${ }^{45}$ gibi fiil anında meydana gelen hâdis kudret ile bağlantılı olarak tanımlamışlardır. Şu halde insanın fiil üzerinde bir rolünün olduğunu belirleyen şey, bu tanımların işaret ettiği üzere, onun, fiil anında kendisinde yaratılan hâdis kudrete mahal/zemin olmasıdır. ${ }^{46}$ Böylece insan, kendisinde yaratılan, edilgeni olduğu hadis kudretin fiili var ediş sürecinde, bir şekilde sürece dahil olup kudreti belli bir fiile yönlendirebilecek bir melekeye sahip olabilmektedir ki bu meleke onun kesbine tekabül etmektedir.

Şu var ki, İmam Eş’arî kesbin hakikî fâilinin Allah olduğunu ve kesbin, O’nun fiili olduğunu söylemektedir. ${ }^{47} \mathrm{Bu}$ yaklaşım insanın, fiili üzerinde herhangi bir etkisinin olmadığını ima etse de Eş‘arî’nin ifade etmeyi amaçladığı şey, bu imanın ötesinde başka bir şey olmalıdır. Nitekim Eş‘arî, bir eylem/hareket olarak kesbin insanda var olduğunu söylerken, bu kesb hareketine onun muktedir kılanın, Allah olması gerektiğini söylemektedir. ${ }^{48}$ Bu açıklama, insanın fiili üzerinde hiçbir etkisinin olmadığı çıkarımına bizi icbâr etmez. Eş'arî̀nin ifadesi -fiil anında insana verilen hâdis kudretin belli bir eyleme yönlendirilmesi anlamina gelen- kesb kabiliyetinin ve yetkinliğinin insana Allah tarafından kazandırıldığı şeklinde de yorumlanabilir. Eş‘arî aktardığımız kanaatinin akabinde Allah'ın bizde kesbi yaratmaması halinde, bizim kesbe sahip olamayacağımızı belirtir. Şu halde ona göre Allah tarafından verilen kesb ile insan, kendi irade ve ihtiyarına dayanarak, Allah tarafından yaratımı sürecinde fiil üzerinde, onun belli bir yönde gerçekleşmesi noktasında etkin olmaktadır. Bu yorum hem Eş̧arîyi kendi içinde tutarlı bir şekilde hem de sonraki takipçilerinin yaklaşımlarını mezhebî bütünlük içinde değerlendirmeye imkân vermektedir. Nitekim Eş'arî zorunlu hareketlerin ve kesbe dayalı hareketlerin Allah tarafından yaratıldıklarını söyledikten sonra, bu söylemin, kesbî hareketlerin de zorunlu olmasını gerektireceği şeklindeki eleştiriye şöyle cevap vermektedir: Zorunlu fiiller, felçlinin hareketi gibi,

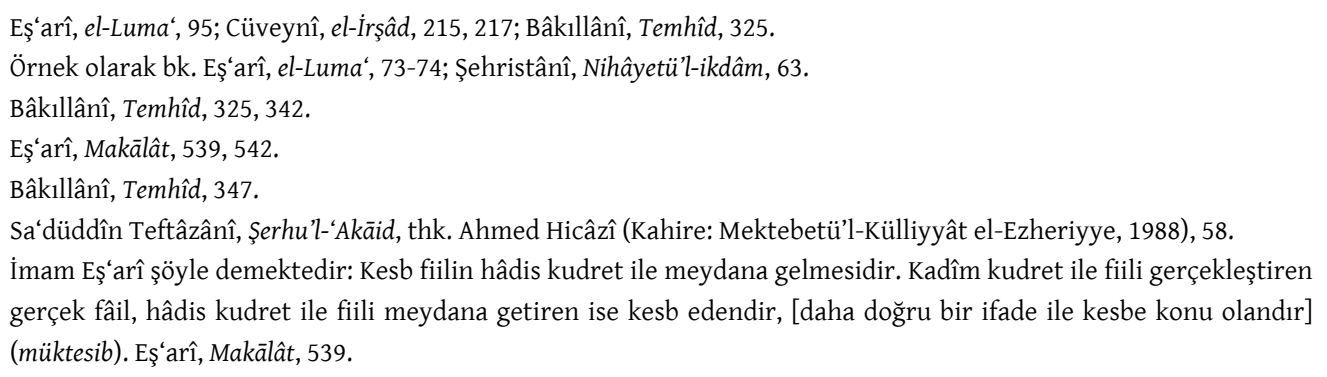


mecbur bırakılan, dayatılan ve çaba gösterilmesine karşın kaçınılamayan fiiller iken, kesbî fiiller ise gelmek, gitmek gibi zorunlu kabul edilemeyeceğini herkesin sağduyusu ile bildiği fiillerdir. Her iki fiil bir hareket/eylem olması yönüyle varoluş ve yaratılma açısından aynı olsalar da kesbî ya da zorunlu olmaları yönüyle birbirinden farklıdırlar; onların yaratılma yönünden aynı olmaları kesb ve zorunluluk yönlerinin de aynı olmalarını gerektirmez. ${ }^{49}$

Onun bu açıklamaları, insanın, kesbî fiillerde fiili yapmaktan kaçınabilme ya da terk edebilme ve bu yönde çaba gösterebilme selahiyetine sahip olduğunu göstermektedir. Nitekim Eş‘arî insanın iman etmeye gücünün (istitâat) yetip yetmediğine ilişkin bir soruya şöyle cevap vermektedir: "Eğer iman etmeye gücünün yetmemesi ile kastettiğiniz şey, kişinin aciz olması ise bunu kabul etmeyiz. Kastettiğiniz, kişinin imanı terk edip başka şeylerle meşgul olması nedeniyle iman etmemesi ise evet [insanın iman etmeye gücü vardır]. ${ }^{{ }^{50}} \mathrm{Bu}$ cevaba göre insanın fiil üzerindeki etkisi, iradesi ve gayreti üzerinden temellendirilmektedir. Şehristânî (öl. 548/1153) de Eş‘arînin görüşünü aktarırken, ona göre Allah'ın, hâdis kudretin akabinde insanın irade ve gayretine göre fiili yarattı̆̆ını söylemektedir. ${ }^{51}$ Eş'arî ayrıca "imanı kesb etti", "inançsızlığı kesbetti” gibi ifadelerin anlamının, iman ve inançsızlığın hâdis kudretle meydana geldiğini ifade ettiğini söyler. ${ }^{52}$ Dolayısıyla ona göre hâdis kudretin fiilin kesb edilmesinde bir etkisi vardır. Zira o, kesbi, kesb edenin hâdis kudreti ile bir şeyin meydana gelmesi şeklinde tanımlar. ${ }^{53}$ Şu halde Eşsarîye göre kudreti de mutlak anlamda kesb etme selahiyetini de insanda yaratan Allah'tır; bu anlamda hakikî fâil Allah'tır. İnsan irade ve ihtiyarı ile kesbini kullanmakta fiil üzerinde belirleyici olmaktadır. Eş̧arînnin kesbi ısrarla Allah'a nispet etmesinin nedeni ise geç dönem Eş‘arîlerinden farklı olarak, kesb kavramını "varlık verme" sürecinin bir unsuru olarak değerlendirmesidir. 0 kesbi fiil anında fiili var eden kudretin etkinliği şeklinde değerlendirir. Kudret varsa kesb vardır. “Allah Teâlâ’nın kendisinde kesbi yaratmadığı kişide kesbin olması imkânsızdır. Kudret olmadan kesb mümkün olmadığına göre kesb kudret için var edilmiştir." ${ }^{.54}$ Fiil kesptir. Fiili var eden Allah ise hakikî kesb eden de O'dur. ${ }^{55}$

Hakikî fâil ve kâsib Allah ise ve kesb yalnızca fiilin meydana geliş sürecinin bir birimi ise kudretten farkı nedir? Bu kavram neyi ifade etmekte ve neden insanla irtibatlı olarak ele alınmaktadır? Görebildiğimiz kadarıyla Eş'arî kesbi, fiilin hâdis kudret ile kendisi üzerinde var olduğu fâili ifade etmek için kullanmaktadır. İnsanın fiili kendisinde var edilen hâdis kudret ile meydana geldiği için başka bir ifade ile insan hâdis kudretin mahalli/zemini olduğu için onun fiili ya da onda meydana gelen fiil kesb diye isimlendirilir. Allah ise hâdis kudretin mahalli olmadığı gibi hâdis kudret ile kādir ve fâil de değildir. Kesbi, hâdis kudreti ve fiili kulda yaratan Allah olsa da kesbi bir kazanım olarak (mükteseb) kendisinde bulunduran, insandır. Kesbi var eden Allah, kesbi kullanan insandır; ancak kesbi var eden olması hasebiyle Allah hakikî fâildir. Bu açıklamada kesb hâdis kudret ile meydana gelen fiili ifade eder. Bu durumda insanın zorunlu fiilleri ile insanın fiilleri

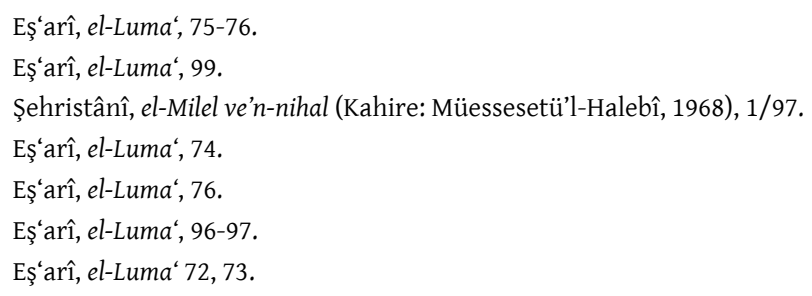


dışında hâdis kudret ile meydana gelen doğal fiiller de kesbî kabul edilmeli midir? Yukarıda da temas edildiği üzer Eş‘arî kesbî fiilleri -var olmaları ve yaratılmaları açısından zorunlu fiiller ile aynı düzlemde değerlendirse de- insanın iradesiyle aktif olması yönüyle zorunlu fiillerden ayırmaktadır. ${ }^{56} \mathrm{Bu}$ durumda Eş'arîyye göre kesbin hâdis kudret ile insan iradesinin kesiştiği düzlemdeki bir etkiyi ifade ettiğini söylemek mümkündür.

Benzer bir değerlendirmeyi Eş‘ârînnin takipçilerinden Bâkıllânı̂'de (öl. 403/1013) de görmek mümkündür. $O$ insanın bütün fiillerini Allah Teâlâ'nın yarattığını, insanın, fiili var etmede bir etkisinin olmadığını ve fiilin -ibâdet ya da günah gibi- belli bir fiil olma yönünü belirleme anlamındaki kesbin Allah tarafından insana verildiğini, insanın irade ve ihtiyarı aracılı̆̆ıyla kesbini kullanarak hâdis kudret aracılığı ile fiil üzerinde etkin olduğunu söyler ${ }^{57}$ ve insanın kesbî fiilinin zorunlu fiilden ayrıștı̆̆ını büyük oranda Eş̧arî̀nin ifadelerine benzer ifade ve deliller ile açıklar ve gerekçelendirir. ${ }^{58}$ Şehristânî (öl. 548/1153), Eş'arînnin görüşünü zikrettikten sonra "Bâkıllânî̀nin ondan bir adım ileri gidip" hâdis kudretin fiilin varlığı üzerinde etkisinin olmadığını, ancak fiilin varlık dışındaki diğer yönlerinde (cihât ve ittibârât) etkisinin olduğunu söylediğini aktarır. Onun aktarımına göre Bâkıllânî, fiilin varlık dışında insana nispet edilen oturmak, kalkmak, namaz kılmak ve oruç tutmak gibi özelliklerinin/yönlerinin olduğunu iddia etmektedir. Ona göre fiilin Allah'a nispet edilen yönlerinin insana nispet edilmesi doğru olmadığ gibi, insana nispet edilen yönlerinin de Allah'a nispet edilmesi doğru değildir. ${ }^{59}$ Eş'arîile Bâkıllânî arasındaki fark muhtemelen kesb kavramının farklı yorumlanmasından kaynaklanmaktadır. Eş̧arî kesbi fiilin gerçekleşmesi (vukū'u'l-fíl) şeklinde tanımlarken, Bâkıllânî kesbi “insanda fiil anında meydana gelen kudret aracılığıyla fiil üzerinde tasarrufta bulunan ve fiilin zorunlu niteliği almasına engel olan yeti" olarak yorumlamıştır. ${ }^{60}$ İlkinde kesb doğrudan fiilin varlığı ile ilişkili iken ikincisinde kesb fiili yönlendiren bir etken olarak değerlendirilmiştir. Kanaatimize göre her iki ilim adamı da fiili var edenin Allah olduğu insanın yalnızca iradesiyle fiilin oluşum sürecine dahil olduğu noktasında hemfikirdir.

Cüveynî de el-irş̧âd ve adlı eserinde var olan her şeyin Allah'ın kudreti ile meydana geldiğini, ${ }^{61}$ hâdis kudretin var olmakla (hudûs) ilgili olduğunu, ${ }^{62}$ ilim ve iradenin fiil üzerinde bir etkisi olmadığı gibi hâdis kudretin de fiil üzerinde hiçbir etkisinin olmadığını söylemektedir. ${ }^{63}$ Burada kudretin fiilin üzerindeki etkisi ile neyin kastedildiği belirgin olarak verilmemiştir. Bununla birlikte hâdis kudret için olumsuzlanan etkinin fiilin gerçekleşmesi (îkā'u'l-makdûr) yönünde bir etki olduğu söylenebilir. Nitekim Cüveynî bu hususu el-Luma adlı eserinde açıç̧a belirtmiştir. ${ }^{64}$ Cüveynî el-'Akidetü'n-Nizâmiyye'de kısmen daha farklı yaklaşım sergiler. o bu eserinde fiillerinin, insanın seçimi ve gücü (iktidâr) ile meydana geldiğini, insanın kudretinin fiili üzerinde hiçbir etkisinin olmadığını söylemenin yanlış olduğunu, bununla birlikte fiilin Allah'ın kudreti ve

56 Bk. Eş'arî, el-Luma', 74-76.

57 Bâkıllânî, Temhîd, 319, 323-324, 341-342.

58 Bâk1llânî, Temhîd, 347.

59 Şehristânî, el-Milel ve'n-nihal, 1/97-98.

60 Bâkıllânî, Temhîd, 347.

${ }^{61}$ Cüveynî, el-İrşâd, 187.

62 Cüveynî, el-İrşâd, 206-208.

63 Cüveynî, el-irşâd, 210.

${ }^{64}$ Cüveynî, Luma'u'l-edille fî kavâidi ‘Akāidi Ehl-i sünne ve'l Cemấa (Beyrut: Alemü'l-kütüb, 1987), 120-121. 
insanın kudreti şeklinde iki kudret ile var olduğunun iddia edilemeyeceğini vurgulamakta, Mu'tezile'yi fiili varoluşunu tek başına insan nispet etmeleri nedeniyle eleştirmektedir. ${ }^{65}$ Fiil iki kudret ile var olamıyorsa ve yaratan yalnızca Allah ise insanın kudretinin etkisi hangi noktada ortaya çıkmaktadır? Cüveynî bu sorun ile ilişkin olarak, Allah'ın insan için bir kudret yarattığını, insanın bu kudreti sahiplendiğini ve filin, insanın sıfatı olan bu kudret ile meydana geldiğini söylemektedir. Ancak bu kudret Allah'ın fiilidir. Zira kudreti yaratmak yalnızca Allah'a aittir. İnsanın hâdis kudreti ile bir fiil var olduğunda bu fiil Allah'a nispet edilir, çünkü o fiil Allah'ın fiili ile yani kudreti yaratması ile meydana gelmiştir. İnsan ise Allah'ın kendisine verdiği seçme hakkı ile bu kudreti belirli fiillere yönlendirmektedir. Dolayısıyla fiili yaratan Allah'tır. ${ }^{66} \mathrm{Bu}$ değerlendirmeye göre Cüveynî hâdis kudretin fiilin gerçekleşmesinde etkisinin olduğunu kabul etmektedir. Ancak kudretin Allah'ın fiili olması hasebiyle O'na nispet edilmesi gerektiğini de vurgulamaktadır. Şu halde insanın fiil üzerindeki etkisi Allah'ın kendisine verdiği irade ile yine Allah'ın verdiği kudret üzerinde yönlendirmede bulunmaktır. Cüveynî'nin Bâkıllânî ve Eş‘arî'den daha fazla insanın etkinliğine dikkat çekse de nihâî kertede ona göre, insanın, fiil ve kudret üzerinde iradeye dayalı yönlendirmenin ötesinde bir etkiye sahip olduğunu söylemek mümkün gözükmemektedir. Benzer bir düşünceyi Fahreddin er-Râzî (öl. 606/1210) de dile getirmektedir. $\mathrm{O}$, namaz ve insan öldürme fiillerinin birer hareket olduğunu, bu fiillerin aslı olan hareketi Allah'ın yarattığını, fiilin namaz ve öldürme gibi belirli/ayrışan vasıflarının kulun kesbi ile gerçekleştiğini ileri sürmektedir. ${ }^{67}$

İmam Eş‘arî ve takipçilerinin yaklaşımları -aralarındaki ifade ve vurgu farklılıkları- göz önünde bulundurulduğunda Eş'arî mezhebinin genel kanaati ile ilgili olarak şunları söylemek mümkündür: Fiil anındaki hâdis kudreti ve onu belli bir fiile yönlendirme selahiyetini (kesb, ihtiyâr) yaratan Allah'tır. İnsan bu selahiyete/kesbe/iradeye dayanarak kendi seçimi ile hâdis kudreti belli bir eyleme yönlendirmekte ve fiili iyi ya da kötü nitelikleri gerçekleştirmektedir. İnsanın sorumluluğu da bu ihtiyarî ve kesbî tasarrufa dayanmaktadır. (Allah en doğrusunu bilendir.)

Eş'arîler'de olduğu gibi Mâtürîdîler'de de fiil anında insanda yaratılan hâdis kudret sürekli olmayan bir arazdır. ${ }^{68}$ Fiili var eden Allah'tır, insan yalnızca kesb eder..$^{69}$ İmam Mâtürîdî fiili var eden gücün Allah'a ait olduğu iddiasını, mahlûkātın tamamının ve yaratılan bütün fiillerin O'na muhtaç olması gerektiği düşüncesine dayandırır. ${ }^{70}$ Bununla birlikte Mâtürîdîler, insanın kendi

65 Cüveynî, el-'Akìdetü'n-Nizâmiyye, 43-44.

66 Cüveynî, el-'Akỉdetü'n-Nizâmiyye, 46-47, 48-49. Cüveynî burada insana hâdis kudreti biçimlendirecek bir seçme hakk1 (ihtiyâr) verildiğini vurguladıktan sonra, Allah'ın yarattı̆̆ı, kudreti fiile yönlendirme yetkisini, efendi-köle örneği üzerinden anlatır. Buna göre kölenin, efendisinin verdiği yetki ve izinle gerçekleştirdiği alış veriş, efendinin izni nedeniyle geçerli olur. Alış verişi efendisinin belirlediği şartlara uygun yapması ya da yapmaması halinde ödül ya da cezâ alacaktır. Fiilin geçerliliği ve izni efendiye ait olsa da verilen izne dayanarak alışverişi bilinçli iradesi ile efendinin taleplerine uygun şekilde gerçekleştirmek kölenin “tasarrufudur”. İnsan fiillerinde bağlamında da benzer şekilde, kudret, kesb ve dileme kabiliyeti Allah tarafından yaratılmış olsa da irade ile fiilin belli bir yönde gerçekleştirmek insana aittir.

67 Teftâzânî, Şerhu'l-Makāsıd (Pakistan: Dârü'l-Me ârifi'n-Numâniyye, 1981), 2/127.

68 Mâtürîdî, Kitâbü't-Tevhîd, 357, 361; Pezdevî, Usûlü'd-dîn, nşr. Hans Peter Linss (Kahire: el-Mektebetü'l-Ezheriyye li'tTurâs, 2005), 123; Nesefî, et-Temhîd, 88.

69 Mâtürîdî, Kitâbü't-Tevhîd, 337; Nesefî, et-Temhîd, 100;

70 Mâtürîdî, Kitâbü't-Tevhîd, 361. 
iradesi ile yaptığı fiilin hakikatte insana nispet edilmesi gerektiğini savunurlar. Mâtürîdî iyi ve kötü ( $t a ̂ a t ~ v e ~ m a ' s ı y y e t)$ fiillerin Allah'a nispet edilmesinin doğru olmadığını, herkesin -Eş'arî̀de de görülen sağduyu deliline benzer şekilde- kendi özünde sağduyusu ile irade sâhibi, fâil ve kesb eden olduğunu idrak ettiğini, fiilin kesb yönüyle hakikî anlamda kula, yaratma yönüyle hakikî anlamda Allah'a ait olduğunu ifade eder. ${ }^{71}$ Ona göre fiilin iki yönü vardır: Birinci, yoktan var etme gibi, insan aklının ve iradesinin erișemeyeceği yönler, diğeri emredilen ya da yasaklanan şeyi yerine getirme gibi insan aklının ve iradesinin erişebileceği yönlerdir. Mâtürîdî ilk yönü itibarıyla fiilin, iradelerinin sınırını aştığı için insanlara nispet edilemeyeceğini, ikinci yönü itibarılyla ise fiilin insanlara nispet edilmesi gerektiği söylemektedir. ${ }^{72}$

Hanefî ve Mâturîdî düşüncenin temsilcilerinde Ebü'l-Pezdevî (öl. 493/1100) de insanların bütün fiillerini Allah Teâlâ'nın yarattığını söyledikten sonra insanın hakikî anlamda fâil olduğunu, fâilin "hâdis kudret ve irade ile fiili meydana getiren kimse" anlamına geldiğini, nihayetinde insanın fiillerinin biri Allah'a diğeri insana ait olmak üzere iki fiil ile var olduğunu söyler. Ancak Allah’ın fiilinin yaratmak ve fiili var etmek, insanın fiilinin ise yaratmanın dışında başak bir şey olduğunu söylemektedir. ${ }^{73}$ Onun düşüncesinin daha belirgin hale gelmesi için insanın fiili ile neyi kastettiğinin tespit edilmesi gerekir. O fiillerinin yaratıldıklarını incelediği başlık altında şöyle bir ifadeye yer verir: "Var etmeyi Allah Teâlâ'ya, fiili ise insana nispet etmemiz gerekir. Çünkü bize göre [insana ait] fiil Allah Teâlâ’nın fiilinin sonucudur (mefûul), insanın fiilinin sonucu değildir. Evet, [netice] o, insanın fiilidir. Fiil ise fiilin sonucundan (mef ûul) başka bir şeydir. Dolayıyla insanın fiili Allah Teâlâ'nın fiili değildir, O'nun fiili insanın fiilinden başka bir şeydir. Allah'ın fiili var etmedir. [Örneğin] oturmak, O'nun fiili değil, fiilinin [yani yaratmasının] sonucudur. Oturmak insanın fiildir; fiilinin sonucu değildir. ${ }^{74} \mathrm{Bu}$ pasaj göstermektedir ki, Pezdevî’ye göre [onun ifadesiyle Hanefîlere göre] insanın fiili, fiil olması yönüyle bir eylemi ortaya çıarmaz. İnsanın fiili, Allah'ın insanda var ettiği mutlak/belirsiz fiile nitelik kazandırmaktan ibarettir. Buna göre Allah'ın fiili yaratmak, fiilinin sonucu ise insanın belli bir fiil sahibi olmasıdır. İnsanın tikel fiili Allah'ın fiilinin sonucu olduğuna göre, bir eylem olması yönüyle fiilin ortaya çıkışında insanın bir etkisi yoktur. İnsan yalnızca ortaya çıkan fiilin niteliğini belirler. Nitekim Pezdevî de bir fiilin birçok yönünün olduğunu, insanın kötü fiillerini bir hareket/fiil olması yönüyle (min haysü hareket) yaratanın Allah olduğunu, ancak onun kötü yönünün Allah'ın yaratması ile meydana gelmediğini, insanın hâdis kudreti ve iradesi ile gerçekleştiğini söylemektedir. ${ }^{75}$

Ebü'l-Muîn en-Nesefî̀nin (öl. 508/1115) yaklaşımı da Pezdevînnin yaklaşımı ile örtüşmektedir. O, insanların fiillerini Allah'ın yarattığını, bununla beraber iyi ve kötü fiillerin insanlara ait olduklarını söyler. ${ }^{76}$ Ona göre insanların fiilleri biri Allah'a ait olan yaratma kudreti (ezelî), diğeri insana ait olan kesb kudreti şeklinde iki kudrete (hâdis) dayanmaktadır. ${ }^{77}$ Ilaveten o, fiilin yaratma ve kesb şeklinde iki anlamı olduğunu belirtmekte, insanın fiilinin, var etme ile değil irade etmekle

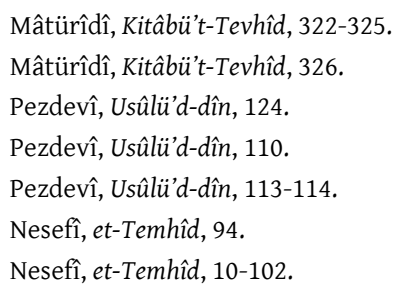


ile ilgili olduğunu ileri sürmektedir. İnsanın fiiline nispet edilen iyi ve kötü gibi nitelikler ( $m a$ ânî) doğrudan Allah'ın fiili olan var etme ile ilgili değildir. Bu nitelikler Allah'ın yaratmasının sonucu meydana gelen, insanın iradî fiilleri ile ilgilidir. Ancak insanın iradesi ile yaptığı etki, Allah'ın fiilinin sonucudur (mef ûl) ve dolayısıyla insanın fiili ve kudreti Allah'ın kudreti altındadır. ${ }^{78} \mathrm{Bu}$ açıklamaya göre Nesefî de Pezdevî gibi hâdis kudret ve kesb ile ifade edilen insana ait fiilin ya da insanın fiil üzerindeki etkisinin yalnızca Allah'ın yarattığı fiile nitelik kazandırmakla sınırlı olduğunu kabul ediyor gözükmektedir. ${ }^{79}$

Neticede Mâtürîdîlere göre, insanın fiilini yaratan Allah'tır ve bir araz olan hâdis kudretin fiilin var oluşu üzerinde bir etkisi yoktur. İnsanın, iradesinin yardımı ile fiilin üzerindeki etkisi ona niteliğini/vasfını kazandırmaktır. Bu etkisi nedeniyle insan hakikî anlamda fâil kabul edilmektedir. İnsanın fâilliğinin anlamı da kesb eden olmasından ibarettir. Kesb kavramında temel belirleyici husus, insanın iradesi ile fiilin niteliğinde belirleyici olmasıdır. Beyâzîzâde'nin (öl. 1098/1687) de vurguladığı gibi Mâtürîdîlerin çoğunluğunun görüşüne göre "fiilin aslı Allah'ın kudreti iledir, fiilin iyi ve kötü (tâat ve ma'slyyet) şeklinde nitelenmesi (vasf) ise kulun kudreti iledir." ${ }^{80}$ Hasılı kesb, fiili meydana getiren şey değil, fâilin fiil ile nitelenmesini gerektiren şeydir. Bunun nedeni de fiilin insanda, insanın kendi iradesine göre yaratılmış olmasıdır. İște Mâtürîdîlerin kesb ile kastettikleri şey de budur. ${ }^{81}$ Mâtürîdîler Allah'ın insana sorumluluk vermesini (teklîf), Eş‘arîlerde olduğu gibi fiil anında etkin olan kesbe değil, fiilden önce kulda bulunan, fiilin, bedenî ve beden dışı araçlarının yeterliliği (selâmetü'l-esbâb) anlamındaki kudrete dayandırırlar. ${ }^{82}$

Mâtürîdîler'in bu yaklaşımı Eş'arîlerin kanaatleriyle büyük oranda örtüşmektedir. Şu farkla ki, Mâtürîdîler kesb nedeniyle insanı hakikî fâil olarak nitelerken, Eş'arîler genel olarak, böyle bir nitelemede bulunmamaktadırlar. Ebü'l-Muîn en-Nesefî ve Sâbûnînnin de belirttikleri üzere Eşarîler ile Mâtürîdîlerin genel kanaatleri mezhebin temel ilkelerinde (fî hakikatil-mezheb) aynıdır. Onlara göre Eş‘ârîler fiili yalnızca yaratma anlamında kullandıkları için insanın etkisinin olduğu alanın fiil olarak nitelemesini kabul etmezler. Ancak bu durum iki ekol arasında esasa

$78 \quad$ Nesefî, et-Temhîd, 96, 104.

79 Nesefî Tebsıra adlı eserinde de hâdis kudretin bir şeyi/fiili var etmediğini, yalnızca var edilen şeyin hâdis kudrete sahip olan kişinin kesbi olmasını gerektirdiğini ifade der. Nesefî, Tebsıratü'l-edille, 2/840.

80 Beyâzîzâde, İşârâtü'l-merâm min 'ibârâti'l-İmam, thk. Yusuf Abdurrezzâk (Karachi: Zam Zam Publisher, 2004 ), 256.

81 Hâlid Nakşibendî, Mâtürîdîlerin, kesbin dışında, aynı anlamı ifade etmek için azm-1 musammam, irade-i cüziyye, kasd-1 cüzî gibi kavramları da kullandıklarını söyler. Hâlid en-Nakşibendî, el-'Ikdü'l-cevherî fi'l-fark beyne kudreti'l-'abd ve kesbihî inde'l-Mâtürîdî ve'l-Eş'arî, thk. Said Fûde (Ürdün: Menşûrât-1 Asleyn, 2016), 49; Beyâzîzâde, İşârâtü'l-merâm, 256, 259.

82 Mâtürîdîler, a) engellerin kalması ve araçların yeterliliği anlamında fiilden önce bulunan ve b) fiil anında yaratılan ve süreksiz biraz olup her an yaratılan şeklinde iki tür kudret kabul ederler. İlki sorumluluk almanın/mükellef olmanın zeminini, ikincisi insanın fiil anındaki kesbinin temelini oluşturur. Mâtürîdî, Kitâbü't-Tevhîd, 356-358; Nesefî, et-Temhîd, 85. Mâtürîdî fiilden önceki kudret hakkında şu değerlendirmeleri yapmaktadır: Fiilden önceki kudret fiilin gerçekleşmesi amacıyla yaratılmış değildir. Bununla birlikte fiiller bu kudret sebebiyle var olur. İnsan, aklı ile bu kudretin nimetini anlar ve ondan bunların şükrünü yerine getirmesi istenir. Şükrü edâ etmesinin yani emirleri ve yasakları yerine getirmesinin şartı, nimetleri ve şükür emrini akledebilmesidir. Nimeti ve emri idrak edemeyene bir sorumluluk yüklenmez. Mâtürîdî, Kitâbü't-Tevhîd, 356. Mâtürîdî’nin bu ifadelerine göre insanın sorumluluğun esas temeli akıl ve emri idrak edebilmektir. 
ilişkin değil, kavram/lafız düzeyinde bir fikir ayrılığını göstermektedir. ${ }^{83}$ Öte yandan Eş‘arînin insanın kesbini Allah'ın fiili olarak değerlendirmesi Eş‘arî ve Mâtürîdî ekollerindeki genel kanaatle kesin bir biçimde çelişmemektedir. Zira Eş'arî kesbin, fiil üzerinde etkin bir durum/fiil/gerçeklik olarak Allah tarafından yaratıldığını savunsa da insanın iradesiyle fiilin gerçekleşme sürecinde bir etkisinin olduğunu, insanın sağduyusu ile zorunlu ve iradî fiilleri birbirinden ayrıştırdığını, zorunlu fiillerden farklı olarak, iradî fiilleri yapmaktan ya da terk etmekten kaçınabileceğini kabul eder. Mâtürîdî ilim adamları da Allah'ın insan da irade ve kudret yarattığını ve insanın bu irade ve kudret ile fiili kesb ettiğini savunsalar da onlar da insanın kesbî ve zorunlu fiilleri arasındaki ayrımı irade kavramı üzerinden açıklarlar. ${ }^{84}$ İmam Eş‘arînin kesbi doğrudan Allah'ın fiili olarak değerlendirmesi dışında hem Eş̧arîlerin hem de Mâtürîdîler'in kesbin mahiyetine yaklaşımlarında bir belirsizlik olduğu ortadadır. Şöyle ki, onlar hâdis kudret ve iradenin -ki bunlar herhangi bir fiil için değil mutlak/kayıtsız anlamıla fiil olması yönüyle fiili varlık bulmasını sağlayan niteliklerdir, dolayısıyla bunlara küllî kudret ve küllî irade denilebilir- insana Allah tarafından verildiğini savunurlar. Bu durumda kesb, kudret ve iradeyi belirli bir fiile evirme eylemidir ve irade ve kudretin dışında başka bir şeydir. Tespit edebildiğimiz kadarıla her iki ekolün kelâmcıları da kesbi bir cevher ya da araz olması yönüyle yapısı/özü itibarıyla değil, "sarf/yönlendirme" şeklinde işlevi üzerinden tanımlamışlardır. Bu durumun kesbin mâhiyetine ilişkin belirsizlikten ileri gelmektedir. Nitekim İmam Mâtürîlî ve Ebü’l-Muîn en-Nesefî, kesbin “açıklanmasına insanın gücünün yetmediği” şey olduğunu söylerken, Sâbûnî (öl. 580/1184) de kesbi ifade ettiği anlam için dilin (ibâre) yetersiz kaldığını söylemiştir. ${ }^{85}$ Bu belirsizlik kesbin mevcut mu yaratılan bir şey mi olduğu sorusunun cevabında da kendini göstermektedir. Eş'arîler kesbin doğrudan Allah tarafından yaratılan bir şey olduğunu söylerken, Mâtürîdîler ise kesbi mevcut olmayan, izâfî araz, itibarî ve ademî bir kavram ya da ne mevcut ne de ma‘dûm bir şey olarak nitelemişlerdir. ${ }^{86}$

83 Nesefî, Tebsıra, 2/846; Sâbûnî, el-Kifâye fi'l-hidâye, thk. Muhammed Aruçi (İstanbul: İSAM Yayınları, 2014), 268-270. Her iki mezhep arasındaki fark için bk. Sıddık Korkmaz, "İnsan Fiillerinin Yaratılması Problemi -Kulların Fiilleri ve Yedi Mezhep Risalesi Örneği-”, Necmettin Erbakan Üniversitesi İlahiyat Fakültesi Dergisi 41 (30 Haziran 2016), 15-38; Mehmet Kalaycı, Tarihsel Süreçte Eşarilik Maturidilik İlişkisi (Ankara: Ankara Okulu Yayınları, 2019), 329. Eş‘arîler ile Mâtürîdîler arasında kesb teorisine ilişkin karşılaştırmalı bir değerlendirme için bk. Veysi Ünverdi, “Eș‘arî ve Ebü’lMuîn en-Nesefî'de Kesb Teorisi”, Diyanet İlmi Dergi 51 (Ocak 2015), 71-100.

84 Pezdevî, Usûlü'd-dîn, 112-114; Nesefî, et-Temhîd, 104; Sâbûnî, el-Kifâye, 268-270. Sabûnî, fiil kavramının kesb ve yaratmayı kapsadığını şöyle açıklar: "Fiil, mümkün bir şeyi imkân halinden zorunlu hâle çevirmektir (sarf). Zorunluluğun anlamı gerçekleşmek ve var olmaktır. Ancak Allah Teâlâ'nın zorunlu hale çevirmesi, aklen mümkün olan bir şeyi var ederek, kulun fiili ise mümkün fiili irade ederek sebeplere tevessül etmesi ile gerçekleşir. Burada fiil kavramı genel, yaratma kavramı yalnız Allah'a ait, kesb kavramı da kula ait olmaktadır." el-Kifâye, 270. Mâtürîdîlerin yaklaşımı ile ilgili geç dönemde yapılan bir değerlendirme için bk. Hayrettin Nebi Güdekli, "Müteahhirîn Dönemi Mâtürîdî Kelâmında İradenin Ontolojisi Sorunu: Saçaklızâde'nin Risâletü'l-irâdeti'l-cüz'iyye'sinin Tahlil, Tahkik ve Tercümesi”, İslam Araştırmaları Dergisi, 41 (31 Ocak 2019), 85-129.

85 Mâtürîdî, Kitâbü't-Tevhîd, 357; Nesefî, Tebstra, 2/780; Sâbûnî, el-Kifâye, 268.

86 Nakşibendî, el-'Ikdü'l-cevherî, 49, 50, 55,57. 
Son olarak belirtmek gerekir ki, Mâtürîdî ve Eş'arî kelâmcılar Mu'tezile'nin çoğunluğu gibi eşya da zorunlu nedenselliği gerektiren tabiat görüşünü reddederler. Onlara göre insan fiilleri de bu genel kanaat kapsamında değerlendirilir. ${ }^{87}$

\section{3. İslam Felsefesinde İnsan Fiilleri}

Felsefeciler ${ }^{88}$ Mebde-i Evvel ve Vâcibü'l-Vücûd diye nitelendirdikleri Allah'in her şeyi bildiğini ve O'nun, kendi iradesi ile her şeyin fâili ve varlık ilkesi olduğunu kabul ederler ${ }^{89}$ Felsefecilere göre âlem Vâcibü'l-Vücûd'dan bilinçsiz ve mutlak anlamda kasıtsız/iradesiz bir şekilde değil, O'nun bilgisi, iradesi ve rızâsı ile sâdır olmuştur. Şöyle ki, O'nun zâtı her şeyin varlık ilkesidir ve her şey O'nun zâtının sonucudur (malûl). Vâcibü'l-Vücûd kendi zâtını bildiği için, zâtından sâdır olan/olacak bütün şeyleri de bilmektedir. O'nun bildiği şey, esasında kendi zâtıdır. Buna göre $O$, bilen, bilinen ve bilgidir. Vâcibü'l-Vücûd kendi zâtını bilince, zâtının ilkesi olduğu her şey O'nun iradesi ${ }^{90}$ ve kudreti ile O'nun rizâsı dâhilinde varlık kazanır. Dolayısıyla O'nun ilmi, iradesi ve kudreti dışında hiçbir şey var olamaz ve ay üstü/ulvî ve ay altı/süflî âlemlerde var olan "her şey O'nun tedbiri, takdiri, ilmi ve iradesiyle" gerçeklik kazanır. ${ }^{91}$ Felsefeciler Vâcibü'l-Vücûd'un

87 Mâtürîdî, Kitâbü't-Tevhîd, 124-125, 192-201; Sâbûnî, el-Kifâye, 68; Bâkıllânî, Temhîd, 60; Cüveynî, el-Irşâd, 234. Ayrica bk. Yusuf Şevki Yavuz, “illiyyet”, Türkiye Diyanet Vakfi İslâm Ansiklopedisi (İstanbul: TDV Yayınları, 2000), 22/121-123. Burada kastettiğimiz vurgulamaya çalıştığımız gibi, zorunlu tabiat görüşüdür. Bunun dışında insanda ya da eşyada zorunlu sonucu gerektirmeyen doğal özlerin ve özelliklerin bulunup bulunmadığı konusu doğrudan konumuza dâhil olmadığı burada bunun tafsiline girmemeyi tercih ettik. Bu konuyla ilgili olarak bk. Alnoor Dhanani, "Mâtürîdî ve Nesefî̀nin Atomculuk ve Tabiat Anlayışı", Büyük Türk Bilgini İmâm Mâtürîdî ve Mâtürî̀îlik Milletlerarası Tartışmalı İlmî Toplantı. (İstanbul: MÜif Vakfı Yayınları, 2012), 65-76. Osman Nuri Demir, "İmam Mâtürîdî'de Akıl, İnsanî Doğa (Tabc) ve Fitrat”, Diyanet İlmi Dergi 56/1 (15 Mart 2020), 181-187. Ahmet Mekin Kandemir, “Mu'tezile'de Zorunlu Nedensellik ve Mucize: Tabiat (Tab') Teorileri Çerçevesinde Bir İnceleme”, Kader 18/1 (30 Haziran 2020), 31-60.

88 Burada felsefeciler ifadesi ile İslam Meşşâ̂i geleneğinin temsilcilerinden İbn Sînâ ve İbn Sînâcı çizgiyi kastediyoruz. Konuya ilişkin incelemede, bu çizgide yer alan Âmirî, İbn Sîna, Behmenyâr, Levkerî ve Ebherî gibi felsefecilerin eserlerine başvurulmuştur. Ömer Mahir Alper, "İbn Sînâ ve İbn Sînâ Okulu”, İslam Felsefesi Tarih ve Problemler, ed. Cüneyt Kaya (İstanbul: İSAM Yayınları, 2017), 279-283.

89 Felsefeciler, kelâmcılarda olduğu gibi zâttan ayrı ve zâta zâit (eklenen) gerçeklikler şeklinde ilâhî sıfatların varlığını, her yönden tek olan Vâcibü'l-Vücûd'da zât-sıfat terkibini (bileşim) gerektirecek olması nedeniyle reddederler. Ancak felsefecilere göre ilim, irade ve kudret gibi sıfatlar, Vâcibü'l-Vücûd'dun, kendisinden sudûr eden mevcutlarla olumlu (îcâbî) ya da olumsuz (selbî) ilişkisini ifade eden izâfî sıfatlar olarak Vâcibü'l-Vücûd'a nispet edilebilirler. Bu noktada mevcutlar üzerinde doğrudan ya da dolaylı etkide bulunan, Vâcibü'l-Vücûd'un zâtı olduğu için sıfatlar O'nun zâtı gibi değerlendirilirler. İbn Sînâ, eş-Şifâ/illâhiyât (Kum: Mektebetü Semâhetü Âyetullah el-Maraşî, 2012), 343-344; İbn Sînâ, "er-Risâletü'l-'arşiyye fî hakāiki't-tevhîd ve isbâti'n-nübüvve”, çev. Mahmut Kaya, İslam Filozoflarından Felsefe Metinleri (ìstanbul: Klasik Yayınları, 2014), 311-313; Levkerî, Beyânü'l-hak bi-zamâni's-sıldk: el'ilmü'l-ilâhî, thk. İbrâhim Dîbâcî (Tahran: Müessese-i Beynelmileli Endişe, 1995), 282-284; Ebherî, Keşfü'l-hakāik fí tahrîri'd-dekāik, thk. Hüseyin Sarığlu (İstanbul, 1988), 350.

90 Belirtmek gerekir ki, felsefeciler ilâhî iradeyi, insanî iradeden ayırmaktadırlar. Beşerî irade kulun seçimine ve seçimini gerçekleştirmek için belirli araçlara bağlı iken, ilâhî iradede böyle bir anlam içerik söz konu değildir. Vâcibü'l-Vücûd, tam olan kendi zâtına âşık olur -ki O, âşık, mâşuk ve hatta aşktır- zâtını tasavvur eder ve kendi zâtından râzı olur. Zâtı, bütün âlemin ilkesi olması hasebiyle, zâtı üzerinden bildiği âlemin en ideal nizâmına da râzı olur ve bu nizâmı bilir. O'nun murâdı işte bu, bildiği ve râzı olduğu âlemin, kendi zâtından taşmasıdır ki (feyz), bu taşma O'nun cömertliğini göstermektedir. Dolayısıyla O'nun iradesi bu cömertlikten başka bir şey değildir. İbn Sînâ, eş-Şifâ/ilâhiyât, 367; İbn Sînâ, “er-Risâletü'l-'arşiyye, 314-315; Behmenyâr, et-Tahsîl (Tahran: İntişârât-1 Dânışkâh-1 Tahran, 1375), 575-578; Levkerî, Beyânü'l-hak, 239-240.

91 Âmirî, İnkāzül'-beșer mine'l-cebri ve'l-kader (Resâil-i Ebi'l-Hasan el-Âmirî), thk. Subhân Halîfât (Amman: el-Câmiatü'lÜrdüniyye, 1988), 258; George F. Hourani, “ibn Sînâ’nın Kaderin Sırrı Risalesi”, çev. Aydın Özdemir, Marife Dini 
mevcûdât ile bu ilişkisini “inâyet” kavramı ile ifade ederler. Nitekim İbn Sînâ (öl. 428/1037) inâyeti şöyle tanımlar: "İnâyet, İlk îlke'nin, özü gereği, varlık âleminin en hayırlı nizâmını bilmesi, ve özü gereği, mümkün âlemde en hayırlı ve yetkin olanın illeti olması ve varlık âleminin en hayırlı ve yetkin haline râzı olmasıdır. Böylece $O$, en hayırlı nizâmı mümkün âlem planında en ideal şekilde akleder ve aklettiği şey, en ideal nizâm ve en hayırlı varlık olarak ondan - mümkün âlem planında eksiksiz nizâmı gerçekleștirmek amacıyla- taşar. İşte inâyetin anlamı budur." ${ }^{92} \mathrm{Bu}$ ifade belirgin bir şekilde âlemin -ki insan fiilleri de bu kapsamdadır- her şeyin ilkesi olan Vâcibü'l-Vücûd'un bilgisi/akletmesi ve rızâsı/iradesi/cömertliği ile meydana geldiğini ortaya koymaktadır. Dolaysıyla felsefecilere göre Vâcibü'l-Vücûd, her şeyin ilkesi ve aynı zamanda her şeyin fâilidir. ${ }^{93}$ Bu yaklaşıma göre $\mathrm{O}$, iyi ve kötü fiillerin de fâili ve ilkesi olmaktadır.

İncelememizle doğrudan ilgili olan, insanların, iyi ve kötü fiillerinin fâili oldukları meselesini ele almadan önce felsefecilerin âlemde kötü (şer) olarak nitelenen fiilleri/olayları nasıl değerlendirdiklerine kısaca temas etmemiz faydalı olacaktır. Felsefecilere göre âlem, bütünü itibarıyla tam ve mümkün âlemler içinde en yetkin (ekmel) olan âlemdir. ${ }^{94}$ Kötülük, âlem için zorunludur ve âlemin tamlığının bir gereğidir. ${ }^{95}$ Felsefeciler kötülüğü, bir şeyin öz yapısının (tab) gerektirdiği niteliklerin/unsurların belirli nedenlerle var olamayıp bilkuvve halde kalması, başka bir ifade ile bilfiil/mevcut olamaması şeklinde tanımlarlar. Şeylerin özlerinin oluşumunda etkin olan illetler belli belirsiz bir rast gelme ('alâ sebîli't-tesâdüf) ile mizaçları/doğal-bileşenleri etkiler ve böylece eksik ya da kötü fitratlar ortaya çıkar. Örneğin insanın oluşumundaki belirli sebepler, insanın özünün/mizacının daha kötü/alçak olmasına ya da bulutlar veya dağlar, güneşin verimliliğine olumsuz etki edebilirler; bunların neticesinde kötülük ortaya çıkar. ${ }^{96}$ Ancak kötülük bu yaklaşımda izâfîdir. Örneğin öfke kuvveti (kuvve-i gazabiyye) akla zarar vermesi itibarıyla kötü kabul edilse de sinir sistemini güçlendirmesi açısından iyidir/hayırlıdır. ${ }^{97}$ Buna göre öfke kuvvetinin özündeki özellik, akıl kuvvetinin özündeki özelliğin varlığına engel olmaktadır. Bu nedenle âlemde var olan her şeyin, özündeki özelliği bilfiil mevcut hale getirerek yetkinleşme ve iyiliğe/hayra erişme meyli, dolaylı olarak âlemde kötülüğe yol açmaktadır. Bir anlamda hayır/iyilik ve kemâl/yetkinlik kötülüğe/şerre ve noksana/eksikliğe neden olmaktadır. Muhtemelen İbn Sînâ "iyilikler kötülüklerin ilkesidir" derken bu anlamı kastetmektedir. ${ }^{98}$ şu

Araştırmalar Dergisi 13/3 (01 Ocak 2013), 171; İbn Sînâ, “er-Risâletü'l-'arşiyye”, 316; i̇bn Sînâ, eş-Şifâ/ilâhiyât, 342, 366; Behmenyâr, et-Tahsîl, 579; Levkerî, Beyânü'l-hak, 339-341. Felsefeciler Vâcibü'l-Vücûd'un irade ve kudretini O'nun ilmi, ilmini de zâtı olarak değerlendirirler. Gazzâlî felsefecilere göre ílk Mebde' olan Allah'ın kudretinin, meşîet-i ezelî olan iradesine, iradesinin de ilmine bağlı olduğunu, nihâî kertede bunların tamamının O'nun zâtını ifâde ettiğini aktarmaktadır. Gazzâlî, Makāsıdü'l-felâsife, thk. Süleyman Dünya (Mısır: Dârü'l-Meârif, 1961), 240. Esasında onlara göre bu sıfatlar, O'nun zâtının, mevcûdât ile ilişkisine göre O'na nispet edilen nitelemelerdir.

92 İbn Sînâ, eş-Şifâ/ilâhiyât, 415; Behmenyâr, et-Tahsîl, 579; Levkerî, Beyânü'l-hak, 365-366.

93 Âmirî, İnkāzü'l-beșer, 258; İbn Sînâ, eş-Şifâ/ilâhiyât, 257-260. Levkerî, fâil kelimesinin artarda (cedîden) varlık veren şeylere de söylendiğini, illk ìlke'den sudûr eden varlığın kesintisiz olduğunu, bu nedenle felsefecilerin O'nun fâilliği için başka bir kavram tercih ettiklerini söyler. Bu, sıfat nispet edilmeksizin, kesintisiz, aracısız, maddesiz ve özü gereği süreksiz var eden anlamında ki “mubdi"” kavramıdır. Beyânü'l-hak, 341-3.

94 İbn Sînâ, "er-Risâletü'l-'arşiyye”, 321; Behmenyâr, et-Tahsîl, 657.

95 George F. Hourani, “íbn Sînâ’nın Kaderin Sırrı Risalesi”, 172; İbn Sînâ, “er-Risâletü'l-'arşiyye”, 321; Levkerî, Beyânü’lhak, 370.

96 İbn Sînâ, “er-Risâletü'l-'arşiyye”, 323; İbn Sînâ, eş-Şifâ/Illâhiyât, 419-417; Levkerî, Beyânüll-hak, 370.

97 Behmenyâr, et-Tahsîl, 659.

98 İbn Sînâ, "er-Risâletü'l-'arşiyye”, 321. 
halde bu açıklamaya ve değerlendirmeye göre âlemdeki kötülük doğrudan tikel illetlere, zamana ve nesnelerin özüne $\left(t a b^{c}\right)$ nispet edildiği için felsefecilere göre kötülük Vâcibü'l-Vücûd'a nispet edilmez. Onlara göre Vâcibü'l-Vücûd'un bütün varlıklara nispeti eşittir ve O'nun âlemde hayırdan başka bir murâdı yoktur. Kötülük yalnızca İlk ìlke'den uzaklaşmanın bir sonucu olarak ay altı âlem için geçerlidir ve âlemin bütünü itibarıyla bir kötülükten söz edilemez. Âlemde kötülük yalnızca hikmetin bir tamamlayıcısı ve/gereği olarak, şeylerin birbirleri ilişkisi çerçevesinde ve illetlerin çokluğu nedeniyle mevcut olur. Varlık iyi ve yetkin, yokluk kötü ve eksik olduğu için, iyilik/hayr varlk âleminin özüne ilişkindir (bizzât), kötülük/şer ise şeylerin özüne ilişen engeller nedeniyle ilintiseldir (bil'araz). ${ }^{99}$

Felsefeciler kötülüğün bu yorumunu kazâ ve kader kavramlarıyla ifade etmişlerdir. İbn Sînâ'nın yaptığı açıklamaya göre kazâ, sırf hayr/iyilik olan İlk İlke'nin [kendi zâtı üzerinden âlemin nizâmını bilmesi, akabinde] ilk aklın O'ndan sâdır olmasıdır. Bu sudûr ve meydana geliş "ilk kasıt (doğrudan varoluş)" diye isimlendirilmiş̧ir. Kader ise İlk illke'den uzak olan ve ilk akıldan sudûr eden sebepli şeylerin var olmasıdır. Bu da "ikinci kasıt (dolaylı varoluş)" diye isimlendirilmiştir. Kader, kötülüğün ortaya çıktığı ve kazâdaki icmâlî varlık sırrının detaylı/tafsîlî olarak gerçeklik kazandığ varoluş evresini ifade eder. ${ }^{100}$ Innsan fiilleri de iyilik ve kötülüğün zemin bulduğu kader kavramının içerdiği 'var oluş evreninde' gerçekleşir.

Kaderî varoluşun bir tezâhürü olarak insan, felsefecilere göre, kısmen de olsa fiilleri üzerinde etkin bir fâil olarak değerlendirilir. Felsefecilere göre fiil, bir şeyin bilkuvve halden bilfiil halde dönüşmesi yani varlığının meydana gelmesidir (husûlü̈l-vücûd). ${ }^{101}$ Fiiller irade sahibi ya da zorunlu fâil tarafından meydana gelebilirler. Ebü'l-Hasan el-Âmirî (öl. 381/992) fiili, fâili üzerinden iradî ve zorunlu olmak üzere iki kısımda ele alır: İrâdî fiillerin kaynağı akıl ya da iç-dış duyular, zorunlu fiillerin kaynağı ise Allah'ın, şeyin doğal yapısına yerleștirdiği öz kuvvet (kuvve-i zâtiyye) ya da şeyin dışında bir kuvvet olduğunu söylemektedir. ${ }^{102}$ İbn Sînâ da bütün fiillerin fâilinin Vâcibü'lVücûd olduğunu söyledikten sonra, fâil türlerini şöyle açılar: Fâil, fiile ilişkin bir bilince sahip olmayıp tek bir fiili meydana getiriyorsa doğal yapıdır ( $(a b)$; fiile ilişkin bir bilince sahip olmayıp birçok fiili meydana getiriyorsa bitkilerin nefsidir; fiile ilişkin bir bilince sahip olup akıl ve bilgiden yoksun ise canlılık nefsidir; fiile ilişkin bir bilincin yanı sıra akıl ve bilgiye sahip olup tek bir fiili meydana getiriyorsa feleklerin nefsidir. Fâil, fiile ilişkin bir bilincin yanı sıra akıl ve bilgiye sahip olup birçok fiili meydana getiriyorsa insan nefsidir. ${ }^{103}$ İbn Sînâ insan nefsini "fikre dayalı irade ve akla dayalı çıkarım ile meydana gelen fiilleri yapması ve tümelleri idrak etmesi yönüyle organik

99 İbn Sînâ, “er-Risâletü'l-‘arşiyye”, 232; George F. Houranii, “ibn Sînâ’nın Kaderin Sırrı Risalesi”, 173; Behmenyâr, etTahsîl, 659, 662 .

100 İbn Sînâ, "er-Risâletü'l-'arşiyye”, 323; ỉbn Sînâ, eş-Şifâ/Ilâhiyât, 439-440. Âmirî de kazâyı bir şeyi var etmek, kaderi ise şeyi, hazırlandığı/amaçlandığı olaya göre düzenlemek şeklinde tanımlar ve ilkinin Allah'ın yaratması için ikincisinin ise yaratılanların özlerine göre artarda meydana gelmesi için kullanıldığına işaret eder. İnkāzu'l-beşer, 264.

101 İbn Sînâ, eş-Şifâ/ilâhiyât, 172. Âmirî de fiili, bir şeyi imkân halinden zorunlu hale çevirmek (sarf) şeklinde tanımlamıştır. İnkāzu'l-beşer, 251.

102 Fiilin kaynağına göre verilen bu kısımların ilki fikrî fiil, ikincisi, şevkî fiil, üçüncüsü tab`î fiil, dördüncüsü kahrî fiil diye isimlendirilmiştir. Bk. Âmirî, İnkāzu'l-beșer, 251-253.

103 İbn Sînâ, “er-Risâletü'l- 'arşiyye”, 315. 
doğal cismin ilke yetkinliğidir" şeklinde tanımamaktadır. ${ }^{104} \mathrm{Bu}$ tanım ve yukarıdaki taksimler, insan nefsinin akıl, ilim, irade kuvvet sahibi olduğunu ve tümelleri idrak ettiğini ortaya koymaktadır. Ancak felsefecilere göre insan nefsi, fiiller üzerinde doğrudan etkin olmayıp, insanda var olan canlılık nefsi ile de irtibatlıdır. Canlılık nefsinin, iç ve dış duyulara bağlı olan idrak kuvveti ve hareket ettiren kuvvet şeklinde iki kuvveti vardır. Hareket ettiren kuvvet de biri harekete yönlendiren (bâ‘is) diğeri hareketi gerçekleştiren kuvvet olmak üzere iki türlüdür. Harekete yönlendiren arzulayıcı (şevki) kuvvet tutku ve öfke (şehvet ve gazab) kuvvetleri, hareketi gerçekleştiren kuvvet sinirler ve kaslardır. ${ }^{105}$ İbn Sînâ aklî değerlendiremeden sonra, tikel bir fiili eylemek üzere bedeni harekete geçiren insan nefsinin, her iki kuvvet ile ilişki akabinde fiile gerçeklik kazandırdığını ileri sürer. Buna göre insan meyledici (mumîle) bir irade ile bir fiili yapmak istediğinde önce onu teorik/bilen (nazrî/'âlime) kuvveti ile tasavvur eder/fikreder; tasavvur, arzu kuvvetini (kuvve-i şevkıyye) harekete geçirir ve durumda fiili yapma isteği kesin irade (câzime) halini alır. İbn Sînâ bu kesin iradeyi, birleştirici güç (icmấ) diye isimlendirir. Birleştirici güç de uzuvları harekete geçirir ve böylece fiil meydana gelir. Şu halde bir tikel fiilin ilk/uzak sebebi insan nefsin teorik/bilen kuvveti, fiile en yakın sebebi ise uzuvlardaki harekete geçiren kas kuvvetidir. Fiilin bu gerçekleşme sürecinde etkin olan ise insan nefsinin kuvvetidir. Kuvvetin "fiili meydana getiren ilke/güç" ${ }^{106}$ olarak tanımlandığı göz önünde bulundurulduğunda fiilin meydana gelmesinde esas/hakikî etkin kuvvet insan nefisidir. Bu nedenle Âmirî insan nefisini "kuvve-i fa âle" (etkin/fiil yapıcı kuvvet) diye isimlendirmiştir. ${ }^{107}$

İnsanın ya da insan nefsinin, fiilleri üzerindeki bu etkinliği onun felsefeciler tarafından bağımsız bir fâil olarak değerlendirildiği düşüncesine kapı aralasa da onların insana en fazla kelâmcılar hatta sünnî kelâmcılar- kadar bir özgürlük alanı açtıklarını söylemek mümkündür; belki de değildir. Çünkü felsefecilere göre ay altı âlemdeki her şey İlk i̇lke olan Vâcibü'l-Vücûd'dan nedensonuç (illet-ma'lûl) ilişkisi içinde sudûr ve feyz etmektedir. Allah'ın iradesi ve ilmi, ilk feyz olan birinci akıldan son tikel varlık nesnesine kadar varlıklar zincirinde yer alan bütün mevcûdâtı kapsamaktadır. Şöyle ki, Vâcibü'l-Vücûd, zâtının "varlık-ilkesi” olması nedeniyle bütün varlık nizamını akletmekte, aynı zamanda bu nizâmı aklen irade etmektedir (irâde-i 'akliyye). Bu akletme ve iradenin bizzat kendisi olan ilâhî ilim, İbn Sînâ'nın ifadesine göre değişmezdir ve bilinen olaya/fiile (malûm) tabi değildir, bilakis olay bu ilme tabidir. ${ }^{108}$ İlaveten, felsefecilerin yakın sebepuzak sebep kavramsallaştırmasına göre kâinattaki bütün varoluş süreçlerini meydana getiren doğudan/yakın nedenler, nihâî planda kuvvet ve ilim yönünden ve fiili belirleyen amaçlar (gâye) yönünden, uzak/dolaylı neden olan İlk İlke'ye bağlıdırlar. ${ }^{109}$ İbn Sînâ et-Talîkāt adlı eserinde nedenlerin kâh birbirleriyle uyuşarak kâh birbirleriyle çakışarak insanın irade ve fiilleri de dahil

104 İbn Sînâ, eş-Şifâ/Nefs, thk. Âyetullah Âmûlî (Kum: Mektebetu'l-ílâmi'l-İslamî, 1375), 55.

105 Âmirî̀, İnkāzü'l-beşer, 252-253; İbn Sînâ, eş-Şifâ/Nefs, 56-57; Behmenyâr, et-Tahsîl, 818-819.

106 İbn Sînâ, eş-Şifâlilâhiyât, 170-171.

107 Âmirî, Inkāzü'l-beșer, 263; İbn Sînâ, et-Ta lîkāt, thk. Abdurrahman Bedevî (Beyrut: Darü'l-İslamiyye, ts.), 16, 18, 51; İbn Sînâ, eş-Şifâ/İlâhiyât, 284-285, 173-174, 367; İbn Sînâ, eş-Şifâ/Nefs, 63-65; Behmenyâr, et-Tahsîl, 790, 804-805, 819.

108 İbn Sînâ, “er-Risâletü’l-'arşiyye”, 313; İbn Sînâ, eş-Şifâ/İlâhiyât, 366.

109 Âmirî İlk İlke’den ilk varlığın meydana gelmesinin (tevellüd) akabinde, ilk varlıktan da eşyanın -yine İlk İlke’in var etmesi aracılığıyla- belli bir tertip ile meydana geldiklerini ve O'nun bütün mevcûdâtın ilk fâili olduğunu söyledikten sonra bu varoluş düzenini duyu-1şık-güneş örnekliğiyle açıklar. Buna göre duyunun/görmenin nedeni 1 şık, 1şı̆̆ın nedeni ise güneştir. İnkāzü'l-beşer, 258. 
olmak üzere âlemdeki bütün olayları meydana getirdiklerini, bunların da feleklerin nefislerine bağlı olduklarını, ${ }^{110}$ nihâyet neden-sonuç zincirindeki her şeyin "bizim fiillerimizin, iradelerimizin ve planlarımızın (tedbîrât)" tamamının Bârî Teâlâ'nın irade ve takdirine dayandığını söylemektedir. ${ }^{111}$ Behmenyâr b. Merzübân (öl. 458/1066) da iradenin hâdis olduğunu, her hâdisin sayısız sebep ile meydana geldiğini irademizin sayısız sebeplerinin feleğin hareketine dayandığını ve feleğin hareketinin İlk ìlke'den sâdır olması nedeniyle "irademizin de aynı şekilde Vâcibü'lVücûd ile ilişki kurduğunu ve irademizin [asıl] sebebinin o olduğunu" ifade eder. ${ }^{112}$

Felsefecilere nispet ederek aktardığımız bu yaklaşım, onların, insanın fiillerinde tamamen bağımsız olamadığı ve kâinatı çevreleyen nedenler-sonuçlar zincirinin sınırlayıcı etkisi altında kaldığı düşüncesine mâil oldukları izlenimi vermektedir. İbn Sînâ’nın şu açılamaları bu izlenimi desteklemektedir: O, insanın iradesinin Vâcibü'l-Vücûd'un iradesinden farkını açıklarken, bize ait idrak melekelerinin, irade ve fiillerin imkân hâlinde (bilkuvve) olduklarını, bunların bize dışarıdan verildiklerini ve mevcut olmak için dışarıdan belirleyici sebebe ihtiyaç duyduklarını, bu belirleyici sebeplerin de [ilâhî] takdirlerle etkinleştirildiklerini, nihâyetinde bizim bütün fiillerimizin bir kader çerçevesinde gerçekleştiklerini dile getirir. ${ }^{113}$ İlk İlke'den neden-sonuç zinciri ile feyz eden hâdiselerden oluşan âlem anlayışının tabiî bir sonucu olarak değerlendirilebilecek bu kanaate göre insanın fiilleri kısmen zorunludur. Nitekim İbn Sînâ yalnızca Vâcibü'l-Vücûd'un hakikî anlamda irade sahibi olduğunu söyler ve bu söylemini O'nun iradesinin doğrudan kendi özünden (min zâtihî) neşet etmesine dayandırır. Fâilin iradesi dışarıdan (min hâricin) bir tercih ettiriciye (müreccih) ya da güdüye (dấi) ihtiyaç duyuyorsa, o hakikî anlamda irade sahibi bir fâil olamaz, ki insanın durumu da böyledir. İnsan hakikî anlamda irade sahibi değildir. Bu nedenle İbn Sînâ insanı "irade sahibi görünümünde mecbur" fâil olarak niteler (muzdarrun fî sûretin muhtârin). Şu halde, felsefecilerin yaklaşımına göre insanın fiil üzerindeki etkinliği ne üzerinden temellendirilmektedir? Kanaatimizce bu temellendirme nefis ve nefsin yeteneklerinin yetkinleștirilmesi üzerine bina edilmektedir.

İbn Sînâ insan nefisinin iki kuvveti olduğunu söyler. ílki büyük öncülleri ve tümel fikirleri elde eden nazarî kuvvettir. İkincisi, ilk kuvvetten aldığı yardım ile insanlar ve diğer canlıların ortak eylem alanlarında faydalı ve zararlı tikeller hakkında görüş (reviyye) üreten amelî kuvvettir. İnsan nefsinin bu iki yönünden ilki olan nazarî kuvvet üst yani yüce ilkelerle ilişkilidir ve ilimlerin kaynă̆ıdır. Nefsin ikinci yönü olan amelî kuvvet ise alt yani beden ve bedenin fiilleri ile ilişkilidir ve ahlâkın kaynağıdır. ${ }^{114}$ İbn Sînâ her iki kuvvetin de yeteneklerini (isti'dâd) geliştirebileceklerini söyler. İlk kuvvet, nazarî aklın yardımı ile ikinci kuvvet ise amelî aklın yardımı ile yeteneğini geliştirir. Bu kuvvetler yeteneklerini geliştirdiklerine kendilerinde kazanılmış yetkinlik (elkemâlül-mukteseb) oluşur. Nefsin nazarî kuvveti doğru, yanlış, zorunlu, imkânsız ve mümkün gibi

110 Örneğin İbn Sînâ şöyle demektedir: İnsanın ölümünün yakın bitişik (vâsll) sebebi mizacının (unsurlardan oluşan bünye) yanmasıdır, bunun sebebi sıcak bir şeyi yemesi veya içmesidir, yemenin sebebi bunu irade etmiş olmasıdır, iradesinin sebebi de feleğin hareketidir. "Bütün bunlar hiçbir beşerin kavrayıp kuşatamayacağı ön sebeplerdir." etTalikkāt, 130.

111 İbn Sînâ, et-Ta'likkāt, 129-131.

112 Behmenyâr, et-Tahsîl, 658.

113 İbn Sînâ, et-Ta lîkāt, 22; Behmenyâr, et-Tahsîl, 578.

114 İbn Sînâ, eş-Şifâ/Nefs, 64-65. 
aklî hükümleri öğrenerek yetkinlik kazanır; amelî kuvveti ise mümkün tikel fiiller hakkında faydalı, zararlı, güzel, çirkin, iyi ve kötü gibi değer yargıları üzerinden görüş (reviyye) üreterek yetkinlik kazanır. ${ }^{115}$ Behmeyâr'ın belirttiğine göre görüş, irade aracıllğıyla, mümkün fiiller arasından tercih edilecek fiili belirler. ${ }^{116}$ Dolayısıyla fiil olması itibarıyla fiilin, fiil olmanın dışında başka yönleri de vardır ve amelî nefis fiilin yönünün belirleyicisidir. Âmirî de fiillerin özü itibarıyla, bizzat fiil olmak, ibâdet ve günah olmak gibi birçok yönü olduğuna dikkat çeker. Ayrıca o, özü itibarıyla fiillerin Bârî Teâlâ tarafından yaratıldıklarını, diğer yönleri itibarıyla, O'na nispet edilememeleri gerektiğini söyler. Ona göre Bârî Sübhânehû, fiillerin ilk var edeni, takdir edip yaratanı ve dolaylı (müvellid) fâili; insan ise fiillerin irade ile kesb edeni, ikinci var edeni ve doğrudan fâilidir. ${ }^{117}$ Şu halde felsefecilere göre insan nefsi amelî aklının yeteneklerini geliştirerek, tercih ve irade edilmeye "layı" ahlâkî değer yargıları üretebilme, akabinde iradesi ile fiilin niteliğini belirleme ve böylece kazanılmış/kesb edilmiş yetkinliğe ulaşma imkânına sahiptir. Nefsin bu imkânı -yukarıda temas edilen, fiilin gerçekleşme sürecindeki diğer kuvvetlerle birliktefiilin varlık kazanmasında temel etkendir. Nitekim Âmirî, fiili ortaya çıkaran gerçek [yakın] kuvvetin, fiili tasavvur eden ve onu [belirleyip] yapmaya karar veren nefis olduğunu söylemektedir. ${ }^{118}$

Neticede felsefecilere göre insan, sonsuz neden-sonuç silsilesinin akışı içinde amelî aklı aracilığıyla fiilleri üzerinde belli bir etkiye/özgürlüğe sahiptir. ${ }^{119}$ Yukarıda aktarılan özeti, özellikle amelî aklın, yüce ilkelere sahip olan nazarî akıldan yardım alarak (istmdâd) fiil ve beden üzerinde tasarrufta bulunuşu göz önünde bulundurulduğunda şusonuca ulaşmak mümkündür: Felsefecilere göre insan ancak canlılık nefsinin kuvvetleri olan tutku ve öfkenin, fiili zorlayıc1 nedenselliğinden kurtulup yüce ilkeleri taşıyan akılların yetkinliğine yaklaşarak yeteneklerini yetkinleștirdiğinde özgür olabilmektedir. Böylece o amelî akıldan ahlâkî değerleri tahsil ederek fiilin oluşum sürecinde belirleyici olan iradeyi etkilemekte ve eylemlerinden sorumlu olmaktadır.

\section{Sonuç ve Değerlendirme}

Mu'tezile, Mâturîdiyye, Eş'ariyye mezhepleri ve Meşşâ̂ felsefe ekolü İslam teorik düşünce geleneğinin etkin ve yaygın ana akımlarını temsil etmektedirler. Bu akımlar arasında düşünce tarihi boyunca tabiat felsefesinden metafiziğe, bilgi felsefesinden nefis teorilerine, ilâhî sıfatlardan âhiret hallerine değin pek çok meselede muhtelif yoğun tartışmalar yaşanmıştır. $\mathrm{Bu}$ tartışmalardan biri de insanın fiilleri üzerindeki etkisinin mâhiyetini tespit etme çalışmalarında ortaya çıkmıştır. Her düşünürün, incelemesini ve çalışmasını içinde varlık bulduğu ilmî çevrenin/geleneğin kavramlarından ve ilkelerinden etkilenerek yürüttüğünü ve belli bir ekolün önemli temsilcileri tarafından yaklaşık ifadelerle dillendirilip savunulan iddiaların mezhebî görüş halini aldığını söylemek yanlıs olmayacaktır. Bu genelleme büyük oranda insan fiilleriyle ilgili tartışmalarda yukarıda adı geçen ekollerin temsilcilerinin yaklaşımları için de geçerlidir. İnsan

İbn Sînâ, eş-Şifâ/Nefs, 284-287.

Behmenyâr, et-Tahsîl, 539.

Âmirî, İnkāzü'l-beşer, 254.

Âmirî, İnkāzü'l-beşer, 262

Belirtmek gerekir ki, bu özgürlüğün mâhiyetinin daha belirgin bir şekilde tespit edilmesi hâlen daha ileri çalışmaların yapilmasını gerektirmektedir. 
fiilleri meselesinde de her mezhep ya da akım kendi görüşünü farklı kavram ve ilkelerle açıklamıştır. Bu çalışmanın ana bölümünde mezheplerin görüşleri kendi ilke ve kavramları üzerinden serimlenmiştir. Bizim burada sorgulamak istediğimiz husus, konuya ilişkin, mezhepleri temsil eden söylemlerdeki görüş ayrilığının, söylenmek istenen maksatlarda da cari olup olmadığıdır. Klasik dönemde yazılan eserlerdeki polemik ve reddiye eksenli açıklamaların ve yorumlanarak veya tahkik edilmeden aktarılan görüşlerin yoğunluğu altında açık bir sentez yapabilmenin zorluğuna rağmen ilk dönem ana metinleri üzerinden bazı çıkarımlar yapmak mümkün görünmektedir.

İnsan fiilleri ile ilgili olarak, mezheplerin ve akımların yaklaşımları incelendiğinde onların, şu üç önermenin kabulü noktasında hassas ve dikkatli oldukları görülür: a) Âlemdeki bütün kuvvetlerin ve fiillerin kaynağı Allah Teâlâ'dır. O'nun bilgisi her şeyi kuşatır. Gücünün yetmeyeceği hiçbir şey yoktur. b) Din dilinde kötü olarak nitelenen hiçbir şey O'na nispet edilemez; hiçbir fiil O'nun kötülükle nitelenmesini gerektirmez. c) İnsan yapıp etmelerinde zorunlu ve mecbur değildir; fiilleri üzerinde belli bir etki imkânına sahiptir ve dolayısıyla sorumluluk alabilir. Bu nedenle yaptıklarından da sorumlu tutulacaktır. Meşşâiyye de dâhil olmak üzere İslam düşüncesinde teorik yönteme bağlı akımlarının hemfikir oldukları bu hususlar üzerindeki ayrışmaları şöyle özetleyebiliriz: Mưtezile ile sünnî kelâmcılar arasındaki tartışma sorumluluğun zeminin ne olduğu ve Allah'a kötülüğün nispet edilip edilemeyeceği meselelerine dayanır. Mu'tezile sorumluluğu fiili var eden kuvvete dayandırmakta ve insanın iyi ve kötü eylemlerinin bu kudret ile var olduklarını savunmaktadır. Onlara göre insanın fiilleri üzerinde Allah'ın kudretinin bir etkisi yoktur. Sünnî kelâmcıların en çok karşı çıtıkları nokta burasıdır. Örneğin, Cüveynî’nin Mu'tezile eleştirilerinin merkezinde, insanın, yaratıcıdan bağımsız tek fâil olduğu düşüncesi (istibdâd) yer alır. Ancak şu var ki, Mu'tezile Allah'ın insanda hâdis fakat sürekli (bâkī) olan kudret arazını yarattığını kabul ettikten sonra insanın, iradesi ile bu kudreti kullandığını ve kudret üzerinde tasarrufta bulunduğunu söylemektedir. Esasında bu anlayışa göre insan, fiilinde yaratıcıdan büsbütün bağımsız değildir; kudreti insana Allah verdiği gibi, O, kudreti insandan her an alabilme imkânına da sahiptir. Sünnî kelâmcılar da benzer şekilde -fiil anı da dahil olmak üzereinsanda her an (müteceddid) hâdis ve araz olan bir kudret yaratıldığını, fiilin bu kudret ile var olduğunu ve insanın kesbi ve iradesiyle bu kudreti yönlendirdiğini kabul ederler. Her iki ekole göre de fiil hâdis kudret ile meydana gelir. Şu halde onların ayrıștıkları temel nokta, kudret arazının sürekli mi yoksa anlık mı olduğudur. Kudret arazının -fiilden önce ya da fiilden sonrainsana dışarından verildiği her iki ekol tarafından kabul edilmektedir. Her iki durumda da onlara göre insanda kudreti yaratan Allah'tır ve kudret Allah'ın fiilidir; insanın O'na muhtaçlığı sürmektedir. Bu ortak zemin üzerinde Mu'tezile kudret arazını, doğrudan onu taşıyan ve kullanan insana nispet ederken, sünnî kelâmcılar kudreti, kudreti kaynağına yani yaratana nispet etmişledir. Bu noktadan sonra tartışma artık kime gerçek fâil, kime yaratıcı (hâllk) denilip denilemeyeceği ile ilgilidir ki bu, terimler üzerinde yapılan (lafzî) bir tartışmadır. Mu'tezile insanı, fiili var eden kudretin mahalli olması hasebiyle gerçek anlamda fâil kabul ederken, sünnî kelâmcılar, fiili yoktan var eden kudretin Allah'a ait olması nedeniyle, hakikî fâilin Allah olması gerektiğinde 1 srar etmişlerdir. ${ }^{120}$ Fiili var eden anlamında fâil olduğu için Mu'tezile kelâmcıları

120 Burada Mâtürîdîlerin kesb eden anlamında insanın hakikî fâil olduğunu ileri sürdükleri de ayrıca hatırlanabilir. Ancak bu durum yukarıda aktarmaya çalıştığımız tartışmanın kapsamına doğrudan dahil değildir. 
insanı, "fiilini yaratan" şeklinde nitelemekten de kaçınmamışlardır. Mu'tezile'nin sünnî kelâmcılar hakkında rahatsızlık duyduğu husus ise onların, kudretin fiil anında yaratıldığı kabul etmeleridir. Zira fiilden önce kudretsiz ve âciz olana insana sorumluluk yüklemek hiç de âdil değildir. Sünnî kelâmcılar bu eleştiri karşısında cevaben dinî/hukukî sorumluluğun, fiilin var olmasının nedeni olan kudrete değil iradeye bağlı olduğunu savunurlar. Sorumluluk fiile ya da fiili var eden güce değil, fiilin belli bir şekilde gerçekleşmesini sağlayan belirleyici iradeye (kesb, 'azmi musammam) dayanmaktadır. Dolayısıyla dinî/hukukî görevleri anlayabilen ve irade edebilen kişiye sorumluluk verilebilir ve o, yaptıklarından sorumlu tutulabilir. Sünnî kelâmın bu yaklaşımı, bir fiilin gerçekleşip gerçekleşmediğini dikkate almaksızın ona azmetmenin suç olup olmadığı ya da -örneğin trafikte kural ihlali yapmadan kazaen ölüme neden olunması durumunda olduğu gibiazmetmeksizin ve irade etmeksizin bir fiilin gerçekleşmesine neden olması halinde kişinin sorumlu tutulup tutulmayacağı gibi hukukî örnekler üzerinden izah edilebilir. Bu husustaki tartışma ise kelâmî olmaktan çok fikhî ve hukukîdir. Ancak şurası açıktır ki, her iki ekol de insanın sorumluluğu için bir zemin temin etmenin öneminin farkındadırlar. Hangi ekolün bu zemini daha sağlam temeller üzerinden tesis ettiğine ilişki tartışma kanaatimizce tâlî ve hukukî bir tartışmadır.

Sünnî kelâmın Mu'tezile ile ayrıştığı diğer nokta kötü fiillerin Allah'a nispet edilmesi meselesidir. $\mathrm{Bu}$ mesele de hâdis kudret ile meydana gelen fiilin kime nispet edileceğine ilişkin tartışma ile doğrudan ilgilidir. Mu'tezile kudreti insana nispet ettiği için, kötü fiillerin insan tarafından var olduklarını savunurken, sünnî kelâmcılar -var edici hâdis kudretin, Allah'ın fiili ve O'nun yarattığı bir şey olması hasebiyle- insanın hâdis kudreti ile meydana gelen kötü ve iyi fiillerin tamamını var eden hakikî fâilinin Allah olduğunu ileri sürerler. Ancak Mu'tezile de, kötü fiiller icra edeceğini bildiği halde Allah'ın insana kudret verdiğini kabul eder. $\mathrm{Bu}$ husus göz önünde bulundurulduğunda, onların, Allah'ın kötülüğe dolaylı olarak izin vermiş olduğunu zımnen kabul etmiş olmaları gerekir. Dolayısıyla kötülük Allah'ın bilgisi dahilinde ve O'nun insana verdiği kudret ile gerçekleşmektedir; ancak varlık kazanması insanın iradesine bağlı olduğu için fiil insana nispet edilmektedir. Sünnî kelâmcılar da benzer şekilde kötü fiili yoktan var edenin ve insanın seçmesine bağlı olarak kötülüğ̈̈n varlık kazanmasını irade edenin Allah olduğunu kabul ederler; ancak onlara göre kötü fiil insanın kesbi ve ihtiyarı gerçekleştiği için insana nispet edilmelidir. Örneğin taşı atarak hareketi gerçekleştiren kişiye 'hareket etme' niteliği nispet edilemeyeceği gibi Allah'a da, insanda, insanın iradesi gereği, örneğin adam öldürme fiilini yaratması nedeniyle "adam öldüren" niteliği nispet edilemez. Neticede her iki ekole göre kötü fiili var edici kudret, Allah tarafından yaratılmakta; fiil iradesi nedeniyle insana nispet edilmektedir. Kanaatimizce bu tartışmada söylemler farklı olsa da söylenmek istenenler yaklaşık olarak aynıdır. Belirtmek gerekir ki, bu tartışma, ilâhî hikmet kavramı hakkındaki yorum farklılığıyla da irtibatlıdır. İnsan fiilleri sorunu ile sınırladığımız elimizdeki çalışmada detaylı olarak incelemekten kaçındığımız bu yorum farklılı̆̆ına ilişkin kısaca şu hususa temas etmekle yetinmek isteriz: Her üç kelâm ekolü de Allah'ın, insanın iradesinden bağımsız olarak, bizzat kendi iradesiyle insanların faydasına olmayan bir şeyi yaratmayacağını kabul ederler. Mu'tezile ve Mâtürîdîyye Allah'ın faydalı ve güzel olanı yarattığını, Eş̧arîler ise O'nun, kemâli gereği, yarattığı her şeyin güzel ve faydalı olduğunu savunur; dolayısıyla her üçü de, Allah'ın hiçbir fiilinin hikmetsiz/abes olmadığını kabul ederler. Her üç ekole göre de kötülüğü var edeceği (Mu'tezile’ye göre) ya da kötülüğün var edilmesi için 
azm ve kesb edeceği (sünnî kelâma göre) bilinen insanın yaratılması bu ilâhî hikmetin dışında değildir.

Burada değinmek istediğimiz diğer husus, felsefecilerin, kelâmcılardan ayrıştıkları, âlemdeki fiillerin zorunlu neden-sonuç ilişkisi içerisinde meydana geldikleri düşüncesidir. Bu düşünce, kelâmcılar açısından, ilk olarak, insan fiillerinin ve eşyada gerçekleşen bütün hareketlerin Allah'tan bağımsız nedenlerle meydana geldiklerini; ikinci olarak, insanın, nedenlerin tahakkümü altında zorunlu bir nesne olduğu fikrini ima etmektedir. Ancak felsefecilerin inâyet teorisi ilk imanın içeriğini doğrudan elemektedir. Zira bu teoriye göre ilim, irade ve kudret sıfatları İlk Illke olan Allah'ın zâtında "bir"dir ve 0 , âlemdeki neden-sonuç zincirinin bütün aşamalarında uzak neden olarak etkindir. Hiçbir fiil O'nun ezelî meşîetinin kapsamı dışında değildir. Şu halde kelâmcıların felsefeciler hakkında bu bağlamdaki yorumlamaları eksik ya da hatalıdır. Ayrıca felsefeciler nedenlerin, iyi ya da kötü tikel sonuçlarının var edici ve varlık verici İlk İlke'ye nispet edilemeyeceğini söylerler. Buna göre nedenlerin etkileşimi ile ortaya çıkan kötü fiiller İlk İlke'ye yani Allah'a nispet edilemez. İnsanın sorumuluğu ile ilgili olarak ise felsefeciler, insanın, canlılık nefsine ait şehvet ve öfke kuvvetlerinin güdüleyici ve iradeyi belirleyici yapısına dikkat çekmiş olsalar da, insanın, amelî aklın yetilerini geliştirebileceğini -ki bunun için onlar, bu çalışmada ele almadığımız, riyâzet, mûsikî, manevî rehberlik gibi muhtelif vasıtalar önerirler- böylece yetkinleşerek, iradeyi belirleyici/zorlayıcı güdülerin tahakkümünden kurtulacağını ve özgürleşeceğini ve dolayısıyla ahlâkî eylemlerle sorumlu olacağını savunurlar.

Hasılı, kelâmî ve felsefî akımlar şu önermede hemfikirdirler: Birincisi: Allah bütün fiillerin kaynağıdır. Bu durum kelâmcılara göre, Allah'ın eşyada ve insanda araz olan hâdis kudreti yaratmasıyla; felsefecilere göre, illk i̇lke'nin bütün tikellerin uzak nedeni olmasiyla izah edilir. Şemseddin es-Semerkandî'nin el-Me'ârif adlı eserinde belirttiği gibi, Allah'ın bütün sebeplerin müsebbibi olduğunda Müslümanlar ittifak etmişlerdir. İkincisi: İnsanın kötü fiilleri Allah’a nispet edilemez. Bu önermeyi Mu'tezile, Allah'ın yarattı̆̆ı hâdis kudret üzerinde tek tasarruf sahibinin insan olduğu kabulüne dayanarak; sünnî kelâmcılar bir fâil olarak Allah'ın, başkasında -o başkası istediği için- var ettiği bir nitelik ile nitelenmesinin doğru olmadığını söyleyerek; felsefeciler ibâdet etmek ve günah işlemek gibi tikel fiillerin niteliklerinin nedenlere nispet edilmeleri gerektiğini savunarak temellendirmişlerdir. Üçüncüsü: İnsan fiillerinden sorumludur. Sorumluluk Mu'tezile'ye göre yaratıldığında insana verilen ve fiilinden önce insanda bulunan hâdis kudrete; Mâtürîdîlere göre fiilin icrâ edilmesini sağlayan hâricî, bedenî ve mâli imkânların hazır olmasına; Eş'arîlere göre iradeyi yönlendiren kesbe; ve felsefecilere göre fiili ortaya çıkaran fâil olarak, insan nefsinin amelî (pratik) aklına dayanmaktadır. Şu halde adı geçen ekol ve akımların, aynı iddiaları farklı söylem ve ifadelerle izah ettiklerini söylemek kanaatimizce yanlış olmayacaktır. Nitekim Âmirî de kelâmcılar ile felsefeciler arasındaki fikir ayrıllğına işaret ettikten sonra bu iki ekol arasındaki ayrışmanın dine zarar veren bir sonuç içermediğine, esasta birbirlerinden farklı şeyler söylemediklerine dikkat çekmektedir. (Allah en doğrusunu bilendir.)

İhtiyatlı birkaç sonuç cümlesini şöyle aktarmak istiyoruz: İnsan fiillerine ilişkin kelâm ekolleri arasında ve kelâm ve Meşşâ̂ felsefe geleneği arasında esasa ilişkin bir görüş ayrilığının olmadığını söylemek İslam düşünce tarihinin metinlerini büsbütün görmezden gelmek anlamına gelir. Bununla beraber, söylenmek istenen benzer maksatların ve fikirlerin, mezhebî değerlere bağlılık, 
siyasi vaziyet, belirli ilkeler üzerinde yoğunlaşan ilmî alaka/titizlik gibi muhtelif sebepler muvacehesinde farklı kavram ve söylemlerle ifade ve izah edildiklerini düşüncesini besleyen ipuçları da mevcuttur. İslam düşünce geleneğinin önemli problemlerinden olan insan fiilleri meselesinde bu türden ipuçlarını yukarıda aktarmaya çalıştık. Sorumuz şudur: İslam düşünce geleneğinin meselelerini, karşıt söylemlerin ve kavramların ardındaki ortak fikirleri ve amaçları keşfetmeyi merkeze alarak incelemek, bu gelenekten istifade etme imkânını artır mı ve böyle bir düşünce tarihi incelemesi mezhebî yöntem ve söylemin sınırlarını genişletip -aşıp değilbirleştirici bir bakış açısı geliştirmenin yolunu açar mı? 


\section{Kaynakça}

Âmirî, Ebü'l-Hasen. İnkāzü'l-beşer mine'l-cebri ve'l-kader (Resâil-i Ebi'l-Hasan el-Âmirî). thk. Subhân Halîfât. Amman: el-Câmiatü'l-Ürdüniyye, 1988.

Alper, Ömer Mahir. “İbn Sînâ ve İbn Sînâ Okulu”. İslam Felsefesi Tarih ve Problemler. ed. Cüneyt Kaya. İstanbul: İSAM Yayınları, 2017.

Bâkıllânî, Ebû Bekr Muhammed b. Tayyib. Temhîdü'l-evâil ve telhîü’d-delâil. Beyrut: Müessesetü'lKütüb es-Sekāfiyye, 1987.

Behmenyâr, Ebü'l-Hasen b. Merzübân el-Acemî el-Âzerbaycânî. et-Tahsill. Tahran: İntişârât-1 Dânışkâh-1 Tahran, 1375.

Beyâzîzâde, Ahmed Efendi. İşârâtü̉'l-merâm min 'ibârâti'l-İmam. thk. Yusuf Abdurrezzâk. Karachi: Zam Zam Publisher, 2004.

Bulgen, Mehmet. Kelâm Atomculuğu ve Modern Kozmoloji. Ankara: TDV Yayınları, 2018.

Cengiz, Yunus. Mu 'tezile'de Eylem Teorisi Kādî Abdülcebbâr Örneği. İstanbul: Düşün Yayınc1lk, 2012.

Cuşemî, Ebû Sa'd el-Hâkim. Tahkîmu'l-‘ukūl fî tashîhi'l-usûl. San'a: Müessesetü'l-İmam Zeyd b. Ali, 2002.

Cüveynî, İmâmü'l-Haremeyn Ebü'l-Meâlî Rüknüddîn Abdülmelik. el-'Akïdetün-Nizâmiyye filerkâni'l-İslamiyye. thk. Zahid Kevserî. Kahire: el-Mektebetü'l-Ezheriyye li't-Turâs, 1992.

Cüveynî, İmâmü'l-Haremeyn Ebü'l-Meâlî Rüknüddîn Abdülmelik. el-İrşâd. thk. Muhammed Yusuf Musa. Mısır: Mektebetü'l-Hâncî, 1950.

Cüveynî, İmâmü'l-Haremeyn Ebü'l-Meâlî Rüknüddîn Abdülmelik. Luma'u'l-edille fî kavâidi ‘Akāidi Ehl-i sünne ve’l Cemâ‘a. Beyrut: Alemü'l-Kütüb, 1987.

Güdekli, Hayrettin Nebi. “Müteahhirîn Dönemi Mâtürîdî Kelâmında İradenin Ontolojisi Sorunu: Saçaklizâde'nin Risâletü'l-irâdeti'l-cüz'iyye'sinin Tahlil, Tahkik ve Tercümesi”. İslam Araştırmaları Dergisi, 41 (31 Ocak 2019), 85-129.

Demir, Osman. Kelâmda Nedensellik İlk Dönem Kelâmcılarında Tabiat ve İnsan. İstanbul: Klasik Yayınları, 2015.

Demir, Osman Nuri. “İmam Mâtürîdı̂'de Akıl, İnsanî Doğa (Tab') ve Fitrat”. Diyanet İlmi Dergi 56/1 (15 Mart 2020), 171-204.

Dhanani, Alnoor. "Mâtürîlî ve Nesefî'nin Atomculuk ve Tabiat Anlayışı". Büyük Türk Bilgini İmâm Mâtürîdî ve Mâtürîdîlik Milletlerarası Tartışmalı İlmî Toplantı. 65-76. İstanbul: MÜí Vakfı Yayınları, 2012.

Ebherî, Esîrüddîn el-Mufaddal b. Ömer es-Semerkandî. Keşfül-hakāik fi tahrîri'd-dekāik. thk. Hüseyin Sarığlu. İstanbul, 1988.

Ebü'l-Hüseyin el-Basrî. Tesaffuhu'l-edille. nşr. Wilferd Madelung. Wiesbaden: Harrasowitz Verlag, 2006. 
Eş'arî, Ebü'l-Hasen Alî b. İsmâîl el-Basrî. el-Luma' fi'r-reddi 'alâ ehli'z-zeyiğ ve'l-bida'. thk. Hammûde Gurâbe. Kahire: Matbaatu Misriyye, 1955.

Eş‘arî, Ebü'l-Hasen Alî b. İsmâîl el-Basrî. Makālâtü'l-İslâmiyyîn. nşr. Hellmut Ritter. Wiesbaden: Franz Steiner Verlag, 1980.

Gazzâlî, Hüccetü'l-İslâm Ebû Hâmid Muhammed b. Muhammed. Makāsıdü'l-felâsife. thk. Süleyman Dünya. Mısır: Dârü'l-Meârif, 1961.

Hourani, George F. “ỉbn Sînâ’nın Kaderin Sırrı Risalesi”. çev. Aydın Özdemir. Marife Dini Araștirmalar Dergisi 13/3 (01 Ocak 2013), 169-189.

İbn Metteveyh, Ebû Muhammed Hasen el-Bahrânî. et-Tezkire fî ahkâmi'l-cevâhir ve'l-a'râz. thk. İbrahim Medkûr. Kahire: Dârü’s-Sekāfe, 1975.

İbn Sînâ, Ebû Alî el-Hüseyn b. Abdillâh. "er-Risâletü'l-'arşiyye fî hakikati't-tevhîd ve isbâti'nnübüvve". çev. Mahmut Kaya. İslam Filozoflarından Felsefe Metinleri. İstanbul: Klasik Yayınları, 2014. İbn Sînâ, Ebû Alî el-Hüseyn b. Abdillâh. eş-Şifâ/ilâhiyât. Kum: Mektebetü Semâhetü Âyetullah elMaraşî, 2012.

İbn Sînâ, Ebû Alî el-Hüseyn b. Abdillâh. eş-Şifâ/Nefs. thk. Âyetullah Âmûlî. Kum: Mektebetu'lİlâmi'l-İslamî, 1375.

İbn Sînâ, Ebû Alî el-Hüseyn b. Abdillâh. et-Ta'lîkāt. thk. Abdurrahman Bedevî. Beyrut: Dârü'lİslamiyye, ts.

Kādî Abdülcebbâr, Ebü'l-Hasen Kād'l-kudât el-Hemedânî. el-Muğnî/İrâde. Kahire: y.y., ts.

Kādî Abdülcebbâr, Ebü'l-Hasen Kādı'l-kudât el-Hemedânî. el-Muhtasar fí usûli'd-dîn (Resâil'ul'adl ve'ttevhîd). thk. Muhammed Ammâre. Kahire: Darü’ş-Şurûk, 1988.

Kādî Abdülcebbâr, Ebü'l-Hasen Kād'l-kudât el-Hemedânî. Şerhu'l-Usûli'l-hamse. Ta'lîk, Ahmed b. elHüseyin Mânkdîm. thk. Abdulkerim Osman. Kahire: Mektebetü Vehbe, 3. Basım, 1996.

Kalaycı, Mehmet. Tarihsel Süreçte Eş̧arîlik Mâtürîdîlik İlişkisi. Ankara: Ankara Okulu Yayınları, 2019.

Kandemir, Ahmet Mekin. "Mu'tezile'de Zorunlu Nedensellik ve Mucize: Tabiat (Tab') Teorileri Çerçevesinde Bir İnceleme”. Kader 18/1 (30 Haziran 2020), 31-60.

Koloğlu, Orhan Şener. Cübbailer'in Kelâm Sistemi. İstanbul: İSAM Yayınları, 2017.

Koloğlu, Orhan Şener. Mu'tezile'nin Felsefe Eleștirisi Harezmli Mu'tezili İbnü'l-Melâhimînnin Felsefeye Reddiyesi. Bursa: Emin Yayınları, 2010.

Korkmaz, Sıddık. "İnsan Fiillerinin Yaratılması Problemi -Kulların Fiilleri ve Yedi Mezhep Risalesi Örneği-”. Necmettin Erbakan Üniversitesi İlahiyat Fakültesi Dergisi 41/41 (30 Haziran 2016), 15-38.

Levkerî, Ebü'l-Abbas Fadl b. Muhammed. Beyânü'l-hak bi-zamâni's-sıdk: el-'ilmü'l-ilâhî. ed. İbrâhim Dîbâcî. Tahran: Müessese-i Beynelmileli Endişe, 1995.

Mâtürîlî, Ebû Mansûr Muhammed b. Muhammed b. Mahmûd es-Semerkandî. Kitâbü't-Tevhîd. thk. Bekir Topaloğlu-Muhammed Aruçi. İstanbul: TDV İslâm Araştırmaları Merkezi (ISAM), 2017. 
Melâhimî, Rüknüddîn Mahmûd b. Muhammed el-Hârizmî. Kitâbu'l-fâik fì usûli'd-dîn. thk. Faysal Bedîr Avn. Kahire: Dârü'l-Kütüb ve'l-Vesâiki'-Kavmiyye, 2010.

Melâhimî, Rüknüddîn Mahmûd b. Muhammed el-Hârizmî. Tuhfetu'l-mütekellimîn fi'r-reddi ale'lfelâsife. thk. Hassan Ansarî. Tahran: Iranian Institute of Philosophy, 2008.

Munâ A. Ebu Zeyd. et-Tasavvuru'z-zerrî. Beyrut: el-Müessesetü'l-Câmi'iyye, 1994.

Nadir, Albert Nasrî. Felsefetü'l-Mu'tezile. İskenderiye: Matbaatu Dârü Neşri’s-Sekāfe, 1950.

Nakşibendî, Hâlid. el-'Ikdü'l-cevherî fi'l-fark beyne kudreti'l-'abd ve kesbihî inde'l-Mâtürîdî ve'l-Eş'arî. thk. Said Fûde. Ürdün: Menşûrât-1 Asleyn, 2016.

Nesefî, Ebü'l-Muîn Meymûn b. Muhammed. et-Temhîd. Kahire: el-Mektebetü'l-Ezheriyye li't-Turâs, 2006.

Nesefî, Ebü'l-Muîn Meymûn b. Muhammed. Tebsiratü'l-edille fí usûli'd-dîn. thk. Enver Hamid İsa. Kahire: el-Mektebetü'l-Ezheriyye li't-Turâs, 2011.

Pezdevî, Sadrü'l-İslâm Ebü'l-Yüsr Muhammed b. Muhammed. nşr. Hans Peter Linss. Usûlü’d-dîn. Kahire: el-Mektebetü'l-Ezheriyye li't-Turâs, 2005.

Razî, Ebû Abdillâh Fahrüddîn Muhammed b. Ömer et-Taberistânî. nşr. Muhammed Abdüsselam Şahîn. el-Metâlibu'l-ấliye mine'l-iilmi'l-ilâhî. Lübnan: Dârü'l-Kütübi'l-'İlmiyye, 1999.

Sâbûnî, Ebû Muhammed Nûruddîn Ahmed el-Buhârî. el-Kifâye fi'l-hidâye. thk. Muhammed Aruçi. İstanbul: İSAM Yayınları, 2014.

Şehristânî, Ebü'l-Feth Tâcüddîn Muhammed. el-Milel ve'n-nihal. Kahire: Müessesetü'l-Halebî, 1968.

Şehristânî, Ebü'l-Feth Tâcüddîn Muhammed. Nihâyetü'l-ikdâm fí illmi'l-kelâm. nşr. Alfred Guillaume. Kahire: Mektebetü's-Sekāfeti'd-Dîniyye, 2009.

Semerkandî, Şemsüddîn Muhammed b. Eşref el-Hüseynî. es-Sahâifu'l-ilâhiyye. Lübnan: Dârü'lKütübi'l-'̇lmiyye, 2007.

Teftâzânî, Sa‘düddîn Mes'ûd b. Fahriddîn el-Herevî el-Horâsânî. Şerhu'l-Makāsıd. Pakistan: Dârü'lMe ârifi'n-Numâniyye, 1981.

Teftâzânî, Sa'düddîn Mes'ûd b. Fahriddîn el-Herevî el-Horâsânî. Şerhu'l-'Akāid. thk. Ahmed Hicâzî. Kahire: Mektebetü'l-Külliyyât el-Ezheriyye, 1988.

Ünverdi, Veysi. “Eș‘arî ve Ebü'l-Muîn en-Nesefî'de Kesb Teorisi”. Diyanet İlmi Dergi 51 (Ocak 2015), 71-100.

Ünverdi, Veysi. "Kādi Abdulcabbâr'da Allah'ın İrâdesinin Sınırlandırılması". Şırnak Üniversitesi Illahiyat Fakültesi Dergisi 3/5 (01 Haziran 2012), 107-126.

Yavuz, Yusuf Şevki. “illiyyet”. Türkiye Diyanet Vakfi İslâm Ansiklopedisi. C. 22/121-123. İstanbul: TDV Yayınları, 2000.

Zemahşerî, Ebü'l-Kāsım Mahmûd b. Ömer el-Hârizmî. el-Minhâc fí usûli'd-dîn. thk. Abbas Hüseyin. San`â: Mektebetü Merkezi Bedri'l-‘ỉmî, 2004. 
Zemahşerî, Ebü'l-Kāsım Mahmûd b. Ömer el-Hârizmî. Mu 'tezile Akaidi Kitabü'l-Minhac Fî Usûli'd-dîn. çev. Ulvi Murat Kılavuz - A. İskender Sarıca. İstanbul: Klasik Yayınları, 2021. 